\title{
On the temperature dependence of organic reactivity, nitrogen oxides, ozone production, and the impact of emission controls in San Joaquin Valley, California
}

S. E. Pusede ${ }^{1}$, D. R. Gentner ${ }^{2}$, P. J. Wooldridge ${ }^{1}$, E. C. Browne ${ }^{1, \mathrm{a}}$, A. W. Rollins ${ }^{1, \mathrm{~b}}$, K.-E. Min ${ }^{3, \mathrm{~b}}$, A. R. Russell ${ }^{1, \mathrm{c}}$, J. Thomas ${ }^{4}$, L. Zhang ${ }^{4}$, W. H. Brune ${ }^{4}$, S. B. Henry ${ }^{5}$, J. P. DiGangi ${ }^{5, d}$, F. N. Keutsch ${ }^{5}$, S. A. Harrold ${ }^{6}$, J. A. Thornton ${ }^{6}$,

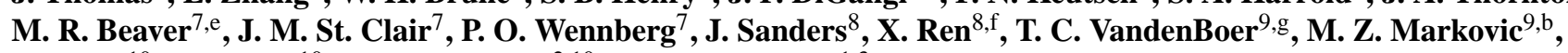
A. Guha ${ }^{10}$, R. Weber ${ }^{10}$, A. H. Goldstein ${ }^{2,10}$, and R. C. Cohen ${ }^{1,3}$

${ }^{1}$ Department of Chemistry, University of California Berkeley, Berkeley, California, USA

${ }^{2}$ Department of Civil and Environmental Engineering, University of California Berkeley, Berkeley, California, USA

${ }^{3}$ Department of Earth and Planetary Sciences, University of California Berkeley, Berkeley, California, USA

${ }^{4}$ Department of Meteorology, Pennsylvania State University, University Park, Pennsylvania, USA

${ }^{5}$ Department of Chemistry, University of Wisconsin Madison, Madison, Wisconsin, USA

${ }^{6}$ Department of Atmospheric Sciences, University of Washington, Seattle, Washington, USA

${ }^{7}$ Divisions of Engineering and Applied Science and Geological and Planetary Sciences, California Institute of Technology,

Pasadena, California, USA

${ }^{8}$ Rosenstiel School of Marine and Atmospheric Science, University of Miami, Miami, Florida, USA

${ }^{9}$ Department of Chemistry, University of Toronto, Toronto, Ontario, Canada

${ }^{10}$ Department of Environmental Science, Policy, and Management, University of California Berkeley, Berkeley, California, USA

${ }^{a}$ now at: Department of Civil and Environmental Engineering, Massachusetts Institute of Technology, Cambridge, Massachusetts, USA

${ }^{\mathrm{b}}$ now at: Earth System Research Laboratory, National Oceanic and Atmospheric Administration and Cooperative Institute for Research in Environmental Sciences, University of Colorado, Boulder, USA

${ }^{c}$ now at: Sonoma Technology, Petaluma, California, USA

${ }^{d}$ now at: Department of Civil and Environmental Engineering, Princeton University, Princeton, New Jersey, USA

enow at: National Exposure Research Laboratory, Environmental Protection Agency, Research Triangle Park, North Carolina, USA

f now at: Air Resources Laboratory, National Oceanic and Atmospheric Administration, College Park, Maryland, USA

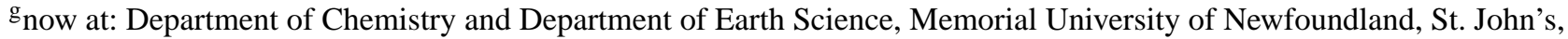

Newfoundland, Canada

Correspondence to: R. C. Cohen (rccohen@berkeley.edu)

Received: 7 October 2013 - Published in Atmos. Chem. Phys. Discuss.: 1 November 2013

Revised: 31 January 2014 - Accepted: 12 February 2014 - Published: 4 April 2014

\begin{abstract}
The San Joaquin Valley (SJV) experiences some of the worst ozone air quality in the US, frequently exceeding the California $8 \mathrm{~h}$ standard of $70.4 \mathrm{ppb}$. To improve our understanding of trends in the number of ozone violations in the SJV, we analyze observed relationships between organic reactivity, nitrogen oxides $\left(\mathrm{NO}_{\mathrm{x}}\right)$, and daily maximum temper-
\end{abstract}

ature in the southern SJV using measurements made as part of California at the Nexus of Air Quality and Climate Change in 2010 (CalNex-SJV). We find the daytime speciated organic reactivity with respect to OH during CalNex-SJV has a temperature-independent portion with molecules typically associated with motor vehicles being the major component. 
At high temperatures, characteristic of days with high ozone, the largest portion of the total organic reactivity increases exponentially with temperature and is dominated by small, oxygenated organics and molecules that are unidentified. We use this simple temperature classification to consider changes in organic emissions over the last and next decade. With the CalNex-SJV observations as constraints, we examine the sensitivity of ozone production $\left(\mathrm{PO}_{3}\right)$ to future $\mathrm{NO}_{\mathrm{x}}$ and organic reactivity controls. We find that $P_{3}$ is $\mathrm{NO}_{\mathrm{x}}$-limited at all temperatures on weekends and on weekdays when daily maximum temperatures are greater than $29^{\circ} \mathrm{C}$. As a consequence, $\mathrm{NO}_{\mathrm{x}}$ reductions are the most effective control option for reducing the frequency of future ozone violations in the southern SJV.

\section{Introduction}

California's San Joaquin Valley suffers extremely poor air quality and has so for decades; violations of health-based ozone standards remain frequent despite statewide ozone control measures (Cox et al., 2009). Understanding trends in frequency of these violations requires knowledge of trends in the chemical drivers of ozone production $\left(\mathrm{PO}_{3}\right)$ - nitrogen oxides $\left(\mathrm{NO}_{\mathrm{x}} \equiv \mathrm{NO}+\mathrm{NO}_{2}\right)$, the reactivity of volatile organic compounds with $\mathrm{OH}$ (VOCR), and the production rate of $\mathrm{HO}_{\mathrm{x}}\left(\mathrm{HO}_{\mathrm{x}} \equiv \mathrm{OH}+\mathrm{HO}_{2}+\mathrm{RO}_{2}\right)$ radicals - along with trends in the sensitivity of local and regional $\mathrm{PO}_{3}$ to these parameters. The sequence of ozone forming reactions is generally known; however, determining the response of $\mathrm{PO}_{3}$ in any location to $\mathrm{NO}_{\mathrm{x}}$ and organic emission reductions is challenging, as $\mathrm{PO}_{3}$ is a nonlinear function of each precursor. Meteorological effects impart variability in the number of $\mathrm{O}_{3}$ violations within a given $\mathrm{O}_{3}$ season but do not, in the average, impact the interannual trends.

In Pusede and Cohen (2012), we examined relationships between nitrogen oxides, the frequency of $\mathrm{O}_{3}$ exceedances, and temperature, which we used as a proxy for VOCR, over the period 1996-2010, inferring from the observed nonlinear nitrogen oxide dependence that chemical production rather than meteorology dominated the statistics of violations in the San Joaquin Valley (SJV). We showed that in the northern $\mathrm{SJV}$ (Stockton plume) and central SJV (Fresno plume) $\mathrm{PO}_{3}$ has largely been sensitive to VOCR and that organic emission reductions led to decreases in the frequency of $\mathrm{O}_{3}$ violations. At high temperatures, $\mathrm{PO}_{3}$ in these plumes is presently $\mathrm{NO}_{\mathrm{x}}$ sensitive. In the southern SJV (Bakersfield plume) at moderate temperatures $\mathrm{PO}_{3}$ has been sensitive to VOCR for most of the record, with organic emissions controls resulting in fewer annual $\mathrm{O}_{3}$ violations; simultaneous $\mathrm{NO}_{\mathrm{x}}$ reductions shifted chemistry to peak $P_{3}$ with respect to $\mathrm{NO}_{\mathrm{x}}$ in 20072010. At high temperatures, southern $\mathrm{SJV} \mathrm{PO}_{3}$ has been at peak production for most of the last $15 \mathrm{yr}$, becoming $\mathrm{NO}_{\mathrm{x}}$ sensitive in 2007-2010; at these temperatures, VOCR reduc- tions have made little impact. This temperature dependence in the observed effects of VOCR controls thus suggested two distinct categories of organic reactivity in the Bakersfield plume: one source that had decreased over the last decade and was more important at moderate temperatures and a second source, dominating at high temperatures, that had not substantially changed over the same time period.

During the California at the Nexus of Air Quality and Climate Change experiment (CalNex-SJV), 18 May-29 June 2010, we measured nitrogen oxides, $\mathrm{OH}$ reactivity, $\mathrm{HO}_{\mathrm{x}}$ source molecules, and a wide suite of individual volatile organic compounds (VOCs) at the San Joaquin Valley supersite allowing new insight into the production rate of ozone in the region. Here, we use these observations to test the response of $\mathrm{PO}_{3}$ to variations in temperature, VOCR, and $\mathrm{NO}_{\mathrm{x}}$. We begin our analysis by describing the temperature dependence of the daytime organic reactivity and categorizing one component of the VOCR that is independent of temperature and a second that increases exponentially with temperature. This simple temperature-response framework allows us to consider how organic emission controls have impacted the total organic reactivity over the last decade and how they will do so over the next $10 \mathrm{yr}$. We use the CalNex-SJV observations to constrain a model of instantaneous $P_{3}$ and then to guide our thinking about the frequency of $\mathrm{O}_{3}$ violations in the complete $2010 \mathrm{O}_{3}$ season. We test various emission reduction scenarios and show both the magnitude and sign of the effects of controls on emissions are temperature dependent.

\section{Chemical production of $\mathrm{O}_{3}$}

\section{1 $\mathrm{PO}_{3}$ reaction sequence}

$\mathrm{PO}_{3}$ is initiated by the oxidation of gas-phase organic molecules. During the daytime, this usually involves reaction with the hydroxyl radical $(\mathrm{OH})$ leading to formation of an alkyl radical (R), which immediately reacts with $\mathrm{O}_{2}$ to form a peroxy radical $\left(\mathrm{RO}_{2}\right)$. In the typical chain-propagating branch of this sequence, $\mathrm{RO}_{2}$ reacts with $\mathrm{NO}$ to form an alkoxy radical (RO) and $\mathrm{NO}_{2}$. In the presence of $\mathrm{O}_{2}$, the $\mathrm{RO}$ leads to formation of $\mathrm{HO}_{2}$ and an aldehyde or ketone. The $\mathrm{HO}_{2}$ in turn reacts with $\mathrm{NO}$ to form a second $\mathrm{NO}_{2}$ molecule and regenerate $\mathrm{OH}$. Hence Reactions (R1-R5) are catalytic, being $\mathrm{HO}_{\mathrm{x}}$ neutral while converting $\mathrm{NO}$ to $\mathrm{NO}_{2}$.

$$
\begin{aligned}
& \mathrm{RH}+\mathrm{OH} \rightarrow \mathrm{R}+\mathrm{H}_{2} \mathrm{O} \\
& \mathrm{R}+\mathrm{O}_{2}+M \rightarrow \mathrm{RO}_{2}+M \\
& \mathrm{RO}_{2}+\mathrm{NO} \rightarrow \mathrm{RO}+\mathrm{NO}_{2} \\
& \mathrm{RO}+\mathrm{O}_{2} \rightarrow \mathrm{R}^{\prime} \mathrm{O}+\mathrm{HO}_{2} \\
& \mathrm{HO}_{2}+\mathrm{NO} \rightarrow \mathrm{OH}+\mathrm{NO}_{2} \\
& \mathrm{Net}: \mathrm{RH}+2 \mathrm{O}_{2}+2 \mathrm{NO} \rightarrow \mathrm{R}^{\prime} \mathrm{O}+\mathrm{H}_{2} \mathrm{O}+2 \mathrm{NO}_{2}
\end{aligned}
$$


The importance of any individual $\mathrm{VOC}$ in the $\mathrm{HO}_{\mathrm{x}}$ cycle depends on its reaction rate with $\mathrm{OH}\left(k_{\mathrm{OH}}\right)$. The rate at which a single organic species reacts with $\mathrm{OH}$ is defined as $\mathrm{VOCR}_{i} \equiv k_{\mathrm{OH}+\mathrm{VOC}_{i}}\left[\mathrm{VOC}_{i}\right]\left(\mathrm{s}^{-1}\right)$; for the entire $\mathrm{VOC}$ mixture, we define the total organic reactivity (VOCR). Throughout this paper we use $\Sigma_{i} \mathrm{VOCR}_{i}$ to refer to the reactivity summed from individually measured compounds; we use VOCR both generally and to refer to the VOCR obtained from direct measurements of the total $\mathrm{OH}$ reactivity. In the continental boundary layer, representative daytime VOCR values are $7-12 \mathrm{~s}^{-1}$ in suburban Nashville, Tennessee (Kovacs et al., 2003); $10-30 \mathrm{~s}^{-1}$ in the polluted megacity Beijing (Lou et al., 2010); and $1-13 \mathrm{~s}^{-1}$ at a rural forest site in Michigan and covarying with daytime temperatures of 10 $27^{\circ} \mathrm{C}$ (Di Carlo et al., 2004).

The photolysis of $\mathrm{NO}_{2}$ gives $\mathrm{NO}\left(\mathrm{NO}_{\mathrm{x}}\right.$ is conserved on timescales of the interconversion between $\mathrm{NO}$ and $\mathrm{NO}_{2}$ ) and a ground-state oxygen atom, which rapidly combines with $\mathrm{O}_{2}$ to form $\mathrm{O}_{3}$ (Reactions $\mathrm{R} 6, \mathrm{R} 7$ ).

$\mathrm{NO}_{2}+h v \rightarrow \mathrm{NO}+\mathrm{O}\left({ }^{3} \mathrm{P}\right)$

$\mathrm{O}\left({ }^{3} \mathrm{P}\right)+\mathrm{O}_{2}+M \rightarrow \mathrm{O}_{3}+M$

For a typical organic molecule, used as a basis for Reactions (R1-R6), the net reaction yields two $\mathrm{O}_{3}$ from one $\mathrm{OH}$ reaction. Variations in this mechanism include compounds that produce one (e.g., carbon monoxide), three (e.g., acetaldehyde), or more $\mathrm{O}_{3}$ molecules.

While $\mathrm{PO}_{3}$ radical chemistry is propagated by reactions involving $\mathrm{HO}_{\mathrm{x}}$ and $\mathrm{NO}_{\mathrm{x}}$, it is terminated by reactions between the same species (Reactions R9-R13, R3'). Herein arises the nonlinear dependence of $\mathrm{PO}_{3}$ on $\mathrm{NO}_{\mathrm{x}}$ and VOCR.

$$
\begin{aligned}
& \mathrm{OH}+\mathrm{HO}_{2} \rightarrow \mathrm{H}_{2} \mathrm{O}+\mathrm{O}_{2} \\
& \mathrm{HO}_{2}+\mathrm{HO}_{2} \rightarrow \mathrm{H}_{2} \mathrm{O}_{2}+\mathrm{O}_{2} \\
& \mathrm{RO}_{2}+\mathrm{HO}_{2} \rightarrow \mathrm{ROOH}+\mathrm{O}_{2} \\
& \mathrm{RO}_{2}+\mathrm{RO}_{2} \rightarrow \mathrm{ROOR}+\mathrm{O}_{2} \\
& \mathrm{OH}+\mathrm{NO}_{2}+M \rightarrow \mathrm{HNO}_{3}+M \\
& \mathrm{RO}_{2}+\mathrm{NO}+M \rightarrow \mathrm{RONO}_{2}+M
\end{aligned}
$$

Reaction (R3') is the minor channel of R3 and, depending on the identity of the VOC, its branching, $k_{\mathrm{R} 3^{\prime}} /\left(k_{\mathrm{R} 3}+k_{\mathrm{R} 3^{\prime}}\right)$, is 0-35\%. Ambient air organic mixtures are observed to have average Reaction (R3') branching ratios in the range of 2$8 \%$ (Perring et al., 2013).

At low $\mathrm{NO}_{\mathrm{x}}$, increasing $\mathrm{NO}$ drives Reaction (R3) and Reaction (R5), and therefore the oxidation of VOCs and $\mathrm{PO}_{3}$. Chemistry in this regime is $\mathrm{NO}_{\mathrm{x}}$-limited and increases in VOCR have little effect on $\mathrm{PO}_{3}$. At higher $\mathrm{NO}_{\mathrm{x}}$ levels, $\mathrm{NO}_{2}$ begins to outcompete organics for $\mathrm{OH}$ (Reaction R13) and the $\mathrm{PO}_{3}$ rate slows. Chemistry here is VOC-limited (also known as $\mathrm{NO}_{\mathrm{x}}$-suppressed or $\mathrm{NO}_{\mathrm{x}}$-saturated). At a given VOCR, $\mathrm{PO}_{3}$ is maximized near the transition point between the $\mathrm{NO}_{\mathrm{x}}-$ and VOC-limited regimes. At peak $\mathrm{PO}_{3}$, the production of alkyl nitrates by Reaction (R3') and peroxy nitrates also reach a peak. The formation of these nitrates is important to the absolute $\mathrm{PO}_{3}$ but has little effect on $\mathrm{PO}_{3}$ 's functional form (Farmer et al., 2011; Perring et al., 2013). When chemistry is VOC-limited, the impact of increasing the VOCR is twofold: (a) it increases the magnitude of $\mathrm{PO}_{3}$ and (b) it shifts the position of peak $P_{3}$ to higher $\mathrm{NO}_{\mathrm{x}}$. Thus, the $\mathrm{NO}_{\mathrm{x}}$ concentration at which $\mathrm{PO}_{3}$ transitions from $\mathrm{NO}_{\mathrm{x}}{ }^{-}$ limited to VOC-limited is VOCR dependent - a dependence that has important implications in the design of organic and $\mathrm{NO}_{\mathrm{x}}$ emission control strategies.

The production of new $\mathrm{HO}_{\mathrm{x}}$ molecules $\left(P \mathrm{HO}_{\mathrm{x}}\right)$ results primarily from the photolysis of $\mathrm{O}_{3}$ (Reactions $\mathrm{R} 14, \mathrm{R} 15$ ), formaldehyde $\left(\mathrm{H}_{2} \mathrm{CO}\right)$ (Reactions R17, R18), nitrous acid (HONO) (Reaction R19), to a smaller extent hydrogen peroxide $\left(\mathrm{H}_{2} \mathrm{O}_{2}\right)$ (Reaction R20), and chemical reactions between $\mathrm{O}_{3}$ and alkenes.

$$
\begin{aligned}
& \mathrm{O}_{3}+h v \rightarrow \mathrm{O}\left({ }^{1} \mathrm{D}\right)+\mathrm{O}_{2} \\
& \mathrm{O}\left({ }^{1} \mathrm{D}\right)+\mathrm{H}_{2} \mathrm{O} \rightarrow 2 \mathrm{OH} \\
& \mathrm{O}\left({ }^{1} \mathrm{D}\right)+\mathrm{N}_{2}, \mathrm{O}_{2} \rightarrow \mathrm{O}\left({ }^{3} \mathrm{P}\right)+\mathrm{N}_{2}, \mathrm{O}_{2} \\
& \mathrm{H}_{2} \mathrm{CO}+h v+2 \mathrm{O}_{2} \rightarrow 2 \mathrm{HO}_{2}+\mathrm{CO} \\
& \mathrm{H}_{2} \mathrm{CO}+h v \rightarrow \mathrm{H}_{2}+\mathrm{CO} \\
& \mathrm{HONO}+h v \rightarrow \mathrm{OH}+\mathrm{NO} \\
& \mathrm{H}_{2} \mathrm{O}_{2}+h v \rightarrow 2 \mathrm{OH}
\end{aligned}
$$

At VOC-limited and peak $P_{3}$, an increase in $P \mathrm{HO}_{\mathrm{x}}$ enhances $P_{3}$ nearly one to one. At $\mathrm{NO}_{\mathrm{x}}$-limited $\mathrm{PO}_{3}, \mathrm{PO}_{3}$ scales approximately as $2 k_{\mathrm{HO}_{2}+\mathrm{NO}}\left(\frac{P \mathrm{HO}_{\mathrm{x}}}{k_{\mathrm{HO}_{2}+\mathrm{HO}_{2}}}\right)^{\frac{1}{2}}$ [NO]. Decreasing $P \mathrm{HO}_{\mathrm{x}}$ also shifts peak $\mathrm{PO}_{3}$ to lower $\mathrm{NO}_{\mathrm{x}}$ but to a smaller extent than the equivalent shift from decreasing VOCR. For example, at $10 \mathrm{~s}^{-1}$ VOCR and $1 \mathrm{ppts}^{-1} P \mathrm{HO}_{\mathrm{x}}$, a $50 \%$ reduction in VOCR shifts peak $P_{3}$ to $\sim 30 \%$ lower $\mathrm{NO}_{\mathrm{x}}$ while the same $P \mathrm{HO}_{\mathrm{x}}$ reduction has half the effect. The photolysis of nitrile chloride $\left(\mathrm{ClNO}_{2}\right)$ also initiates radical chemistry in the early morning (e.g., Osthoff et al., 2008; Thornton et al., 2010; Mielke et al., 2011). $\mathrm{ClNO}_{2}$ is not included in our model (described below) as we focus on daytime chemistry from 10:00-14:00 LT (local time) when $\mathrm{ClNO}_{2}$ is no longer present in relevant amounts.

\subsection{Analytical model of $\mathrm{PO}_{3}$}

We compute $\mathrm{PO}_{3}$ with an analytical model similar to that described by Murphy et al. (2007) and Farmer et al. (2011). We summarize our specific formulation here. This calculation assumes $\mathrm{HO}_{\mathrm{x}}$ is in steady state (Eq. 1).

$$
\begin{aligned}
& P \mathrm{HO}_{\mathrm{x}}=L \mathrm{HO}_{\mathrm{x}}=2 k_{\mathrm{HO}_{2}+\mathrm{HO}_{2}}\left[\mathrm{HO}_{2}\right]^{2} \\
& +2 k_{\mathrm{HO}_{2}}+\mathrm{RO}_{2}\left[\mathrm{HO}_{2}\right]\left[\mathrm{RO}_{2}\right]+2 k_{\mathrm{RO}_{2}}+\mathrm{RO}_{2}\left[\mathrm{RO}_{2}\right]^{2} \\
& +k_{\mathrm{NO}_{2}+\mathrm{OH}}\left[\mathrm{NO}_{2}\right][\mathrm{OH}]+\alpha k_{\mathrm{NO}+\mathrm{RO}_{2}}[\mathrm{NO}]\left[\mathrm{RO}_{2}\right]
\end{aligned}
$$


During daytime Eq. (1) is an accurate approximation, as radical propagation (R1-R5) dominates termination (Reactions $\mathrm{R} 9-\mathrm{R} 13, \mathrm{R} 3$ '). $\mathrm{RO}_{2}$ production approximately equals that of $\mathrm{HO}_{2}$ and, also by the steady-state relation, $\mathrm{RO}_{2}$ loss. This simplifying framework gives Eq. (2) for both $\mathrm{RO}_{2}$ and $\mathrm{HO}_{2}$ with $\alpha$ as the alkyl nitrate branching ratio. Peroxy nitrates are treated to be in thermal equilibrium with $\mathrm{NO}_{2}$ and acyl peroxy radicals and therefore do not contribute to net radical formation.

$\left[\mathrm{RO}_{2}\right] \sim\left[\mathrm{HO}_{2}\right]=\frac{\mathrm{VOCR}[\mathrm{OH}]}{(1-\alpha) k_{\mathrm{NO}+\mathrm{RO}_{2}}[\mathrm{NO}]}$

Equations (1) and (2) are combined to solve for $\mathrm{OH}$ and $\mathrm{HO}_{2}$ with $\mathrm{PO}_{3}=\left(k_{\mathrm{NO}+\mathrm{HO}_{2}}+k_{\mathrm{NO}+\mathrm{RO}_{2}}\right)[\mathrm{NO}]\left[\mathrm{HO}_{2}\right]$ when $\alpha \ll 1$. Details are given in Appendix A.

The observational inputs to the calculation are $\mathrm{NO}$ and $\mathrm{NO}_{2}$, the total VOCR, $P \mathrm{HO}_{\mathrm{x}}, \alpha$, and temperature. In our analysis, VOCR, $P \mathrm{HO}_{\mathrm{x}}$, and the $\mathrm{NO}$ to $\mathrm{NO}_{\mathrm{x}}$ ratio are fit as exponential functions of temperature and we use these fits to constrain the model; VOCR, $P \mathrm{HO}_{\mathrm{x}}$, and $\alpha$ are discussed below.

Total VOCR is equal to the measured $\mathrm{OH}$ reactivity minus the $\mathrm{OH}$ reactivities of $\mathrm{NO}, \mathrm{NO}_{2}, \mathrm{HONO}, \mathrm{HNO}_{3}$, ammonia $\left(\mathrm{NH}_{3}\right)$, and sulfur dioxide $\left(\mathrm{SO}_{2}\right)$.

$P \mathrm{HO}_{\mathrm{x}}$ is the summed $\mathrm{HO}_{\mathrm{x}}$ production rates of $\mathrm{O}_{3}, \mathrm{H}_{2} \mathrm{CO}$, $\mathrm{HONO}$, and $\mathrm{H}_{2} \mathrm{O}_{2}$ photolysis and $\mathrm{O}_{3}$ reactions with alkenes. The contributions of $\mathrm{O}_{3}$ and $\mathrm{H}_{2} \mathrm{CO}$ were 34 and $26 \%$, respectively. Noontime HONO concentrations during CalNexSJV were between 30 and 250 ppt (Ren et al., 2011; VandenBoer et al., 2013) making HONO an important daytime radical source $(32 \%) . \mathrm{H}_{2} \mathrm{O}_{2}$ photolysis $(1 \%)$ and $\mathrm{O}_{3}+$ alkene reactions (7\%) are less important to the daytime total. Photolysis frequencies are computed with the TUV (total ultraviolet) calculator (http://cprm.acd.ucar.edu/Models/ TUV/Interactive_TUV) (Madronich, 1987) at $1 \mathrm{~h}$ resolution for a clear sky day (7 June 2010) and used to scale the 1 min measured photosynthetically active radiation to capture changes with cloud cover. The $\mathrm{O}_{3}$ optical depth used is $300 \mathrm{DU}$, measured by OMI (ozone monitoring instrument) on 7 June 2010 (http://www.temis.nl/protocols/O3total.html) (Veefkind et al., 2006). The measurement altitude of the CalNex-SJV site is $0.14 \mathrm{~km}$ a.s.l. The surface albedo, 0.08 , was determined using the MODIS 16 day $500 \mathrm{~m}$ product in band $3(459-479 \mathrm{~nm})$ for 18 June 2010. The product was reprojected at a fine resolution $\left(0.001^{\circ}, \sim 10 \mathrm{~m}\right)$ for the CalNex-SJV site-specific surface reflectivity. The photolysis rates were reduced by $10 \%$ so that calculated $P \mathrm{HO}_{\mathrm{x}}$ $\sim L \mathrm{HO}_{\mathrm{x}}$. We attribute the adjustment in photolysis frequencies to error associated with selection of TUV model input parameters. $P \mathrm{HO}_{\mathrm{x}}$ is averaged over the 10:00-14:00 LT window.

An effective $\alpha$ value is inferred from observations of $\mathrm{O}_{\mathrm{x}}$ $\left(\mathrm{O}_{\mathrm{x}} \equiv \mathrm{O}_{3}+\mathrm{NO}_{2}\right)$ and total alkyl nitrates ( $\left.\Sigma \mathrm{ANs}\right)$ as two divided by the slope of their correlation (Perring et al., 2013). Deriving $\alpha$ this way treats $\mathrm{O}_{\mathrm{x}}$ and $\Sigma$ ANs concentrations as proxies for their respective production rates and assumes that, on average, two $\mathrm{O}_{3}$ are produced per unit VOCR. During CalNex-SJV the daily average $\alpha$ is $2-3 \%(2 \sigma)$ and we use $2.5 \%$ as a constant in our calculation. The $\mathrm{NO}_{\mathrm{x}}$ value at peak $\mathrm{PO}_{3}$ is sensitive to $\alpha$, where a lower $\alpha$ value gives $\partial \mathrm{PO}_{3} / \partial \mathrm{NO}_{\mathrm{x}}$ equal to zero at higher $\mathrm{NO}_{\mathrm{x}}$. Variability in $\alpha$ of $\pm 0.5 \%$ is not large enough to affect our results.

\section{Observations}

\subsection{CalNex-SJV measurements}

CalNex was a multi-site, multi-platform field intensive that took place in the spring of 2010 across California (Ryerson et al., 2013). The San Joaquin Valley supersite (CalNexSJV) was located at the University of California Extension - Kern County $\left(35.346^{\circ} \mathrm{N}, 118.965^{\circ} \mathrm{W}\right)$. Daytime (10:0014:00 LT) winds to the site were consistently from the northwest and at on average $2-3 \mathrm{~m} \mathrm{~s}^{-1}(\sim 1 \sigma)$. The CalNex-SJV site was $6 \mathrm{~km}$ southeast of downtown Bakersfield and typically less than an hour downwind.

Continuous in situ observations of over 100 VOCs, $\mathrm{H}_{2} \mathrm{CO}$, peroxy acyl nitrate (PAN), peroxypropionyl nitrate (PPN), $\mathrm{C}_{1}-\mathrm{C}_{3}$ organic acids, glyoxal, carbon monoxide (CO), methane $\left(\mathrm{CH}_{4}\right)$, total $\mathrm{OH}$ reactivity, $\mathrm{NO}, \mathrm{NO}_{2}, \mathrm{HNO}_{3}, \mathrm{NH}_{3}$, $\mathrm{SO}_{2}, \Sigma$ ANs, $\mathrm{O}_{3}, \mathrm{H}_{2} \mathrm{O}_{2}$, and meteorological parameters (e.g., temperature, relative humidity, and photosynthetically active radiation) were collected from 18 May to 29 June 2010 atop an $18 \mathrm{~m}$ walk-up tower. HONO was measured at a lower tower level $15.3 \mathrm{~m}$ above ground. Table B1 lists the measurement uncertainty, instrumental technique, and associated reference(s) for each species used in this analysis. All observations are at $1 \mathrm{~min}$ time resolution with the following exceptions: VOCs $(1 \mathrm{~h}), \mathrm{NH}_{3}$ and $\mathrm{SO}_{2}(1 \mathrm{~h}), \mathrm{OH}$ reactivity (10 min), and HONO (2 min). Acetaldehyde, the firstgeneration isoprene oxidation product methyl vinyl ketone (MVK), ethane, and benzene were not measured. Their concentrations were calculated via relationships with observed species (see Appendix B for details).

Throughout this analysis we use daily average concentrations (10:00-14:00 LT), as our focus is the day-to-day rather than time-of-day variability. Daily averages of hourly VOC data are 10:00-14:30 LT in order to include five data points. We use the daily maximum $1 \mathrm{~h}$ temperature at the CalNexSJV site (the maximum temperature over the entire day not just the 10:00-14:00 LT window) unless otherwise noted. The daily maximum temperature is well correlated with the daily average temperature: slope $=0.91( \pm 0.03), y$ intercept $=4.72( \pm 0.70)^{\circ} \mathrm{C}$, and $R^{2}=0.99$. Skies were mostly cloudless during CalNex-SJV with the measured daily average photosynthetically active radiation (PAR) independent of temperature at daily maximum temperatures greater than $22{ }^{\circ} \mathrm{C}$. 


\section{2 $\mathrm{O}_{3}$ season routine monitoring observations}

We include monitoring network measurements of the daily $1 \mathrm{~h}$ maximum temperature, hourly $\mathrm{O}_{3}$, and the $8 \mathrm{~h}$ maximum average $\mathrm{O}_{3}$ product. These data are collected and maintained by the California Air Resources Board and the San Joaquin Valley Air Pollution Control District (http://www.arb.ca.gov/adam/index.html). The temperature data are from the Bakersfield Meadows Airport $\left(35.331^{\circ} \mathrm{N}\right.$, $\left.119.001^{\circ} \mathrm{W}\right)$. The $\mathrm{O}_{3}$ data are the average of the Bakersfield, 5558 California Avenue, $\left(35.357^{\circ} \mathrm{N}, 119.063^{\circ} \mathrm{W}\right)$ and Edison $\left(35.346^{\circ} \mathrm{N}, 118.852^{\circ} \mathrm{W}\right)$ sites. We discuss the $\mathrm{O}_{3}$ data as the daily average (10:00-14:00 LT) and in terms of the frequency of exceeding the California $8 \mathrm{~h}$ maximum average standard of $70.4 \mathrm{ppb}$.

Throughout this manuscript we define low, moderate, and high temperature regimes as follows: low - daily maximum temperatures of $17-27^{\circ} \mathrm{C}$ (days between 1 May-31 October), moderate - daily maximum temperatures of $28-33^{\circ} \mathrm{C}$, and high - daily maximum temperatures of $34-45^{\circ} \mathrm{C}$. In 2010 there were 38 low temperature days, 54 moderate temperature days, and 80 high temperature days. These temperature cutoffs were selected in order to be consistent with Pusede and Cohen (2012). We also refer to the 2010 average low, moderate, and high temperatures, $24.7^{\circ} \mathrm{C}, 30.8^{\circ} \mathrm{C}$, and $36.4^{\circ} \mathrm{C}$, which are averages of the $20101 \mathrm{~h}$ daily maximum temperature record and not of the $1 \mathrm{~h}$ daily maximum temperatures observed during the cooler, springtime CalNex-SJV study period. We use the average temperatures to streamline the discussion of our results. All figures in the manuscript are plotted along the $x$ axis of daily maximum temperature spanning $15-40^{\circ} \mathrm{C}$. There were three days in 2010 when the daily maximum temperature exceeded $40^{\circ} \mathrm{C}$.

\section{Results and discussion}

\subsection{Organic reactivity and temperature}

Organic and $\mathrm{NO}_{\mathrm{x}}$ emissions arise from multiple sources. Some sources are largely independent of temperature, for example emissions from motor vehicle exhaust and baseload power plants; others are known to increase exponentially with temperature such as biogenic emissions and the evaporation of gasoline. We examine observed daytime (10:0014:00 LT) relationships between reactivity and temperature of more than 120 individual organic compounds and find that reactivities can be broadly categorized as either temperature independent or temperature dependent. We emphasize the observed temperature dependence is driven primarily by temperature's effect on VOC concentrations (presumably emissions) rather than by acceleration of the $\mathrm{OH}$ reaction rates. In Fig. 1 we show the empirically determined fits of all observed organic molecules (10:00-14:00 LT) as a function of the daily maximum temperature.The $\Sigma_{i} \mathrm{VOCR}_{i}$ are grouped

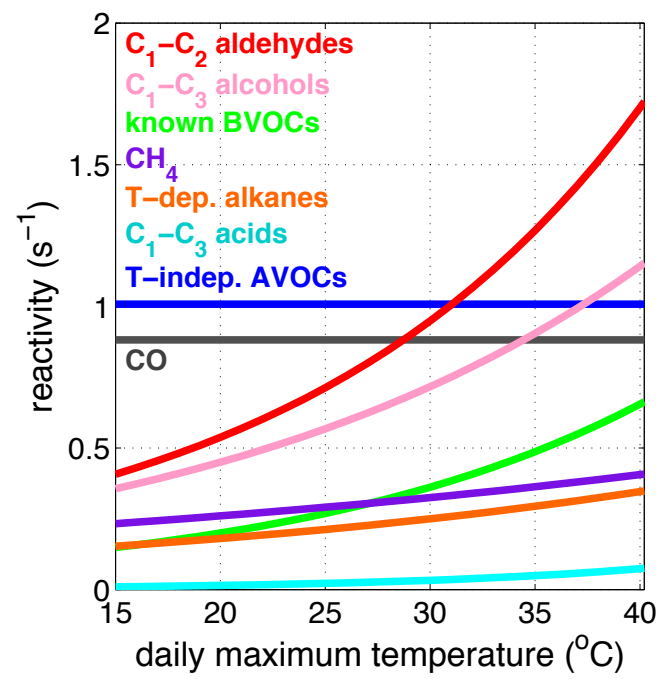

Fig. 1. Empirical fits of the daily average (10:00-14:00 LT) $\Sigma_{i} \operatorname{VOCR}_{i}\left(\mathrm{~s}^{-1}\right)$ versus daily maximum temperature $\left({ }^{\circ} \mathrm{C}\right)$. Data points for each curve are shown in Fig. B1. Colors are as follows: $\mathrm{C}_{1}-\mathrm{C}_{2}$ aldehydes (red), $\mathrm{C}_{1}-\mathrm{C}_{3}$ alcohols (pink), known biogenic VOCs (green), $\mathrm{CH}_{4}$ (purple), temperature-dependent alkanes (orange), $\mathrm{C}_{1}-\mathrm{C}_{3}$ organic acids (cyan), $\mathrm{CO}$ (gray), and temperatureindependent AVOCs (blue). For a listing of the mean $\mathrm{VOCR}_{i}$ of each molecule see Table B2.

by chemical functionality when possible and we prioritize simplicity (the fewest number of groupings) over groupings by source category ${ }^{1}$. Figure 1 also includes reactivity contributions from four unmeasured species using computed concentrations. Each VOC included in Fig. 1 is listed in Table B2 (see Appendix B for details). The data points summarized in Fig. 1 are shown in Fig. B1.

In Fig. 1 we find that the daily average $\Sigma_{i} \mathrm{VOCR}_{i}$ of certain anthropogenic VOCs (AVOCs) and CO is independent of temperature; the reactivities of $\mathrm{C}_{1}-\mathrm{C}_{2}$ aldehydes, $\mathrm{C}_{1}-\mathrm{C}_{3}$ alcohols, known biogenic VOCs, $\mathrm{CH}_{4}$, a subset of alkanes

\footnotetext{
${ }^{1}$ For example, ethanol and methanol both have hydroxyl functional groups; however, their emission sources are distinct. Ethanol sources include evaporative emissions from decaying organic matter on farms (e.g., Alanis et al., 2010; Howard et al., 2010a, b; Malkina et al., 2011) and vehicle combustion (e.g., de Gouw et al., 2012); methanol sources include emissions from dairy wastes and also from living plants in forests and fields (e.g., Karl et al., 2001; Schade and Goldstein, 2001; Galbally and Kirstine, 2002; Fares et al., 2012). We observe that the alcohols' temperature dependence are also different, the exponential temperature dependence of methanol being more pronounced than that of ethanol (solid and dashed lines, respectively, in Fig. B1b). A second example is in the known biogenic grouping of isoprene, various monoterpenes, oxidation products of these emissions, et alia (Table B2). Isoprene and monoterpenes are emitted from different plant species, are transported to the CalNex-SJV site from different distances, and exhibit unique light, humidity, and (very high) temperature dependence (Guenther et al., 1993).
} 
and $\mathrm{C}_{1}-\mathrm{C}_{3}$ organic acids increase exponentially with increasing temperature. We find that at low and moderate temperatures, temperature-independent AVOCs and CO represent the largest portion of $\Sigma_{i} \mathrm{VOCR}_{i}$. At high temperatures, the small oxygenates, $\mathrm{H}_{2} \mathrm{CO}$, acetaldehyde, and $\mathrm{C}_{1}-\mathrm{C}_{3}$ alcohols, dominate. The known biogenic source is only a minor contributor to VOCR in the southern SJV even at the highest temperatures $\left(10 \%\right.$ of $\Sigma_{i} \mathrm{VOCR}_{i}$ and $5 \%$ of VOCR at $\left.36.4{ }^{\circ} \mathrm{C}\right)$.

In Fig. $2 \Sigma_{i} \mathrm{VOCR}_{i}$ and VOCR are organized according to temperature dependence: temperature-independent $\Sigma_{i} \mathrm{VOCR}_{i}$ (blue), known temperature-dependent $\Sigma_{i} \mathrm{VOCR}_{i}$ (yellow), and unknown temperature-dependent reactivity (green). The temperature-independent $\Sigma_{i} \mathrm{VOCR}_{i}$ has a mean value of $2.1 \mathrm{~s}^{-1}$; it is equal to the sum of temperatureindependent AVOCs, $\mathrm{CO}, 0.2 \mathrm{~s}^{-1} \mathrm{H}_{2} \mathrm{CO}$, and $0.15 \mathrm{~s}^{-1}$ temperature-dependent alkane $\Sigma_{i} \mathrm{VOCR}_{i}$. Light-duty vehicles are known to emit these molecules, the largest portion of this vehicular source (70-90\%) being temperatureindependent tailpipe emissions (Pierson et al., 1999; Rubin et al., 2006; Gentner et al., 2009). An aside: the temperature-dependent alkane $\Sigma_{i} \mathrm{VOCR}_{i}$ category has been further divided into temperature-dependent and temperatureindependent components, henceforth associating the $\sim y$ intercept value of $0.15 \mathrm{~s}^{-1}$ (Fig. 1 orange line) with vehicle emissions (i.e., temperature-independent $\Sigma_{i} \mathrm{VOCR}_{i}$ ) and the remaining reactivity, having a distinctly temperature-driven source, with evaporative emissions from gasoline vehicles and fugitive emissions from petroleum operations (Gentner et al., 2013a).

The temperature-dependent $\Sigma_{i} \mathrm{VOCR}_{i}$ and temperaturedependent VOCR, the latter defined here as the measured $\mathrm{OH}$ reactivity minus the temperature-independent $\Sigma_{i} \mathrm{VOCR}_{i}$ and $\mathrm{OH}$ reactivities of $\mathrm{NO}, \mathrm{NO}_{2}, \mathrm{HONO}, \mathrm{HNO}_{3}, \mathrm{NH}_{3}$, and $\mathrm{SO}_{2}$, are also shown. A comparison of these data indicates a portion of the reactivity is unaccounted for by VOC observations. This unknown reactivity is temperature dependent, increasing from $\sim$ zero at low temperatures to $\sim 5 \mathrm{~s}^{-1}$ at high temperatures. Our estimate for $\mathrm{VOCR}_{\text {acetaldehyde }}$ is uncertain (Appendix B). We include VOCR acetaldehyde in Figs. 1 and 2 , as we are interested in the magnitude of the unknown as opposed to the unmeasured VOCR. Measurement uncertainties in $\mathrm{HONO}, \mathrm{HNO}_{3}, \mathrm{NH}_{3}$, and $\mathrm{SO}_{2}$ cannot fill the observed gap in reactivity at high temperatures. The total mean hightemperature reactivity of these species is $0.15 \mathrm{~s}^{-1} \pm 21 \%$, or at most $0.18 \mathrm{~s}^{-1}$, as $>85 \%$ of this reactivity is from $\mathrm{NH}_{3}$ (Table B1).

Identifying what molecules/sources are responsible for the unknown organic reactivity is not the aim of this work but we are able to establish the temperature response of the unknown source(s). We note that it has been previously speculated that a missing source of VOCR is important when $\mathrm{O}_{3}$ is high in the SJV (Steiner et al., 2008; Hu et al., 2012; Pusede and Cohen, 2012). Organic sources with this temperature dependence include molecules with emission rates controlled by their vapor pressures, biogenic VOCs from forests

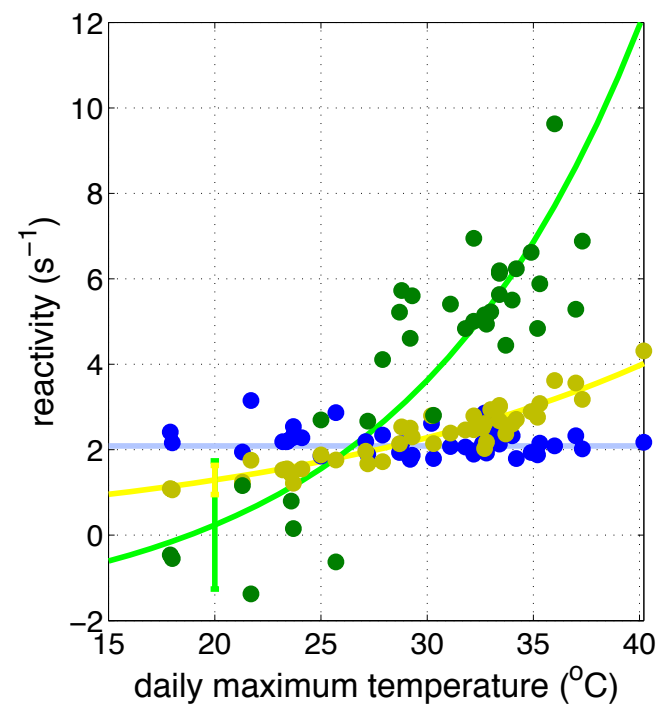

Fig. 2. Daily average (10:00-14:00 LT) organic reactivity $\left(\mathrm{s}^{-1}\right)$ versus the daily maximum temperature $\left({ }^{\circ} \mathrm{C}\right)$ with fits: temperature-independent $\Sigma_{i} \mathrm{VOCR}_{i}$ (blue), temperature-dependent $\Sigma_{i} \mathrm{VOCR}_{i}$ (yellow), and temperature-dependent VOCR (green). The temperature-dependent VOCR is equal to the measured $\mathrm{OH}$ reactivity minus the temperature-independent $\Sigma_{i} \mathrm{VOCR}_{i}$ and minus the $\mathrm{OH}$ reactivities of $\mathrm{NO}_{2}, \mathrm{NO}, \mathrm{HONO}, \mathrm{HNO}_{3}, \mathrm{NH}_{3}$, and $\mathrm{SO}_{2}$. The mean temperature-independent $\Sigma_{i} \mathrm{VOCR}_{i}$ is $2.1 \pm 0.3_{1}(1 \sigma)$ (light blue line). The unknown reactivity is thus temperaturedependent and is the difference between the yellow and green curves. The error bars are the sum of the squared $y$ residuals (divided by the number of points less 2 ) and are $\pm 0.3_{4}$ (yellow) and \pm 1.5 (green).

(e.g., Guenther et al., 1993) and cultivated fields, as well as the oxidation products of these emissions (e.g., Huisman et al., 2011; Mao et al., 2012). In the southern SJV, known organic sources likely to be temperature dependent are diverse and are arranged in an overlapping patchwork surrounding the CalNex-SJV site. These sources include emissions from dairy wastes (e.g., Shaw et al., 2007; Gentner et al., 2013a) and animal feeds (Alanis et al., 2010; Howard et al., 2010a, b; Malkina et al., 2011), biogenic emissions from crops (e.g., Ormeño et al., 2010; Fares et al., 2011, 2012; Gentner et al., 2013b; Park et al., 2013a) and forests in the adjacent Sierra Nevada foothills (e.g., Schade and Goldstein, 2001; LaFranchi et al., 2011; Park et al., 2013b), and the evaporative emissions of oil and gas extraction activities, as suggested by our observation of temperature-dependent light alkane mixing ratios.

In Pusede and Cohen (2012) - using temperature as a proxy for VOCR - we showed that the frequency of $8 \mathrm{~h} \mathrm{O}_{3}$ violations in Bakersfield and the southern SJV region at moderate temperatures fell substantially from 1999-2010 because of VOCR reductions; the same was not true at high temperatures and we concluded that there were two reasons for 


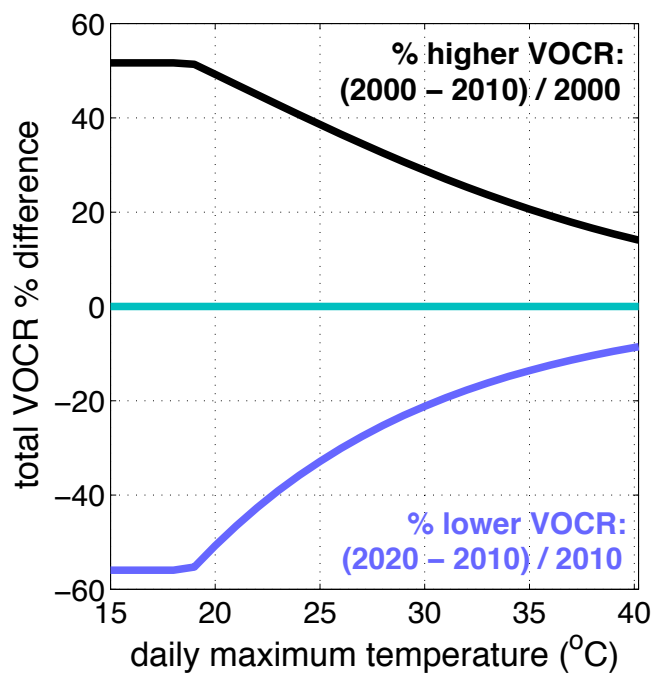

Fig. 3. The effects of organic emission reductions on the total VOCR versus daily maximum temperature $\left({ }^{\circ} \mathrm{C}\right)$. We assume here that the temperature-independent $\Sigma_{i} \mathrm{VOCR}_{i}$ of $2.1 \mathrm{~s}^{-1}$ has decreased and will continue to decrease at a rate of $6 \% \mathrm{yr}^{-1}$ and that the temperature-dependent reactivity has been and will continue to be unchanged. The percent difference (higher) in the total VOCR in 2000 , $\left(\mathrm{VOCR}_{2000}-\mathrm{VOCR}_{2010}\right) / \mathrm{VOCR}_{2000}$, is in black. The percent change (lower) in the total VOCR in 2020 , $\left(\mathrm{VOCR}_{2020}-\right.$ $\mathrm{VOCR}_{2010}$ )/VOCR 2010 , is in periwinkle. The turquoise line is the year 2010 at $0 \%$.

this ${ }^{2}$. (1) At moderate temperatures $\mathrm{O}_{3}$ chemistry was VOClimited for most of the record and, as such, the exceedance frequency was sensitive to changes in VOCR. At high temperatures, $\mathrm{O}_{3}$ chemistry was near peak $P_{3}$, and recently (2007-2010) $\mathrm{NO}_{\mathrm{x}}$-limited on weekends, and thus less sensitive to VOCR decreases. (2) There were two distinct categories of organic reactivity in the southern SJV - one source that had decreased over the last decade and was more important at moderate temperatures and a second source that dominated at high temperatures and had not substantially changed.

In light of the CalNex-SJV $\Sigma_{i}$ VOCR $_{i}$ and VOCR observations and well-documented efforts to control motor vehicle emissions (e.g., Kirchstetter et al., 1999a, b; Parrish et al., 2002; Harley et al., 2006; Parrish, 2006; Bishop and Stedman, 2008) we speculate that it is the temperatureindependent reactivity that has decreased over the last decade. At the same time, we know of no deliberate attempt to control the molecules dominating the reactivity at high temperatures - small aldehydes, alcohols, and the unknown VOCR. It is therefore likely that the temperatureindependent $\Sigma_{i} \mathrm{VOCR}_{i}$ of $2.1 \mathrm{~s}^{-1}$ is the endpoint of longterm efforts at organic emission reductions.

\footnotetext{
${ }^{2}$ Pusede and Cohen (2012) did not include an analysis at low temperatures because exceedances at these temperatures were infrequent or did not occur.
}

Routine summertime VOC canister sampling in the southern SJV (Appendix B) suggests a decrease of $\sim 6 \% \mathrm{yr}^{-1}$ in temperature-independent emissions. In what follows, we use this $-6 \% \mathrm{yr}^{-1}$ rate in the temperature-independent $\Sigma_{i} \mathrm{VOCR}_{i}$ and assume no change in temperature-dependent emissions to illustrate the effects of VOC controls from 2000 to 2010 on the total VOCR (Fig. 3). We show that over the last decade the impact of reductions on the total VOCR (black) have been greatest at low temperatures (50-35\%) and smallest at high temperatures $(20-15 \%)$. We show the predicted percent change in total VOCR in the next decade, assuming the temperature-independent $\Sigma_{i} \mathrm{VOCR}_{i}$ continues to decrease at the same rate (periwinkle). Again, the impacts are largest at low temperatures (55-25\%) and smallest at high temperatures $(15-10 \%)$. An interesting feature in Fig. 3 is that the temperature dependence becomes more prominent in the future as the temperature-independent component declines.

\subsection{Combined $\mathrm{NO}_{\mathrm{x}}$ and temperature dependence}

$\mathrm{NO}_{\mathrm{x}}$ decreases by $\sim 60 \%$ from weekdays $(5.3 \mathrm{ppb}$ ) to weekends (2.3 ppb) and is observed to be temperature independent (Fig. 4a). In Fig. 4b, we combine relationships between temperature, total VOCR, and $\mathrm{NO}_{\mathrm{x}}\left(\right.$ as $\mathrm{NO}_{\mathrm{x}} \mathrm{R} \equiv \mathrm{NO}_{\mathrm{x}}$ reactivity with $\mathrm{OH})$. On weekends, VOCR/NO $\mathrm{N}$ R is more than double that on weekdays. On weekdays and weekends the observed VOCR/ $\mathrm{NO}_{\mathrm{x}} \mathrm{R}$ increases across the temperature range of 15$40^{\circ} \mathrm{C}$ by a factor of 5 and 10 , respectively.

Figure $4 \mathrm{~b}$ suggests that the combined $\mathrm{NO}_{\mathrm{x}}$ and VOCR relationships with temperature impart a dependence on temperature of the sensitivity of $\mathrm{PO}_{3}$ to its precursor emissions. To investigate this, we calculate $\mathrm{PO}_{3}$ as described in Sect. 2.2 using the temperature relationships of VOCR, $P \mathrm{HO}_{\mathrm{x}}$, and $\mathrm{NO} / \mathrm{NO}_{\mathrm{x}}$ observed during CalNex-SJV (Figs. 5a-c). $P \mathrm{HO}_{\mathrm{x}}$ increases with increasing temperature. This temperature dependence is driven by the $\mathrm{HO}_{\mathrm{x}}$ source molecules $\mathrm{O}_{3}, \mathrm{HONO}$, and $\mathrm{H}_{2} \mathrm{CO}$, each increasing with increasing temperature so that the relative contributions are similar across the $15-40{ }^{\circ} \mathrm{C}$ range. $\mathrm{NO} / \mathrm{NO}_{\mathrm{x}}$ decreases with increasing temperature, this ratio being set by the $\mathrm{O}_{3}$ concentration (Fig. 5d). For context, we also show the daily average (10:00-14:00 LT) $\mathrm{O}_{3}$ during CalNex-SJV (magenta) and over the entire $2010 \mathrm{O}_{3}$ season (1 May-31 October) (gray). Fitting the $2010 \mathrm{O}_{3}$ (gray) versus daily maximum temperature to a line (not shown) yields a weekday slope that is $28 \%$ steeper on weekdays than on weekends.

Large changes in $\mathrm{NO}_{\mathrm{x}}$, like those occurring weekday to weekend, impact $\mathrm{OH}$ concentrations; this change in $\mathrm{OH}$ has a feedback on VOCR and $\mathrm{NO}_{\mathrm{x}}$. Higher $\mathrm{OH}$ reduces total VOCR, as oxidized organic molecules are usually less reactive than their parent VOC. OH has the same functional form as $\mathrm{PO}_{3}$ and, analogously, is least responsive to changes in $\mathrm{NO}_{\mathrm{x}}$ near peak $\mathrm{PO}_{3}$. Higher average weekday $\mathrm{O}_{3}$ (gray) at high temperatures indicates chemistry is $\mathrm{NO}_{\mathrm{x}}$-limited (a 


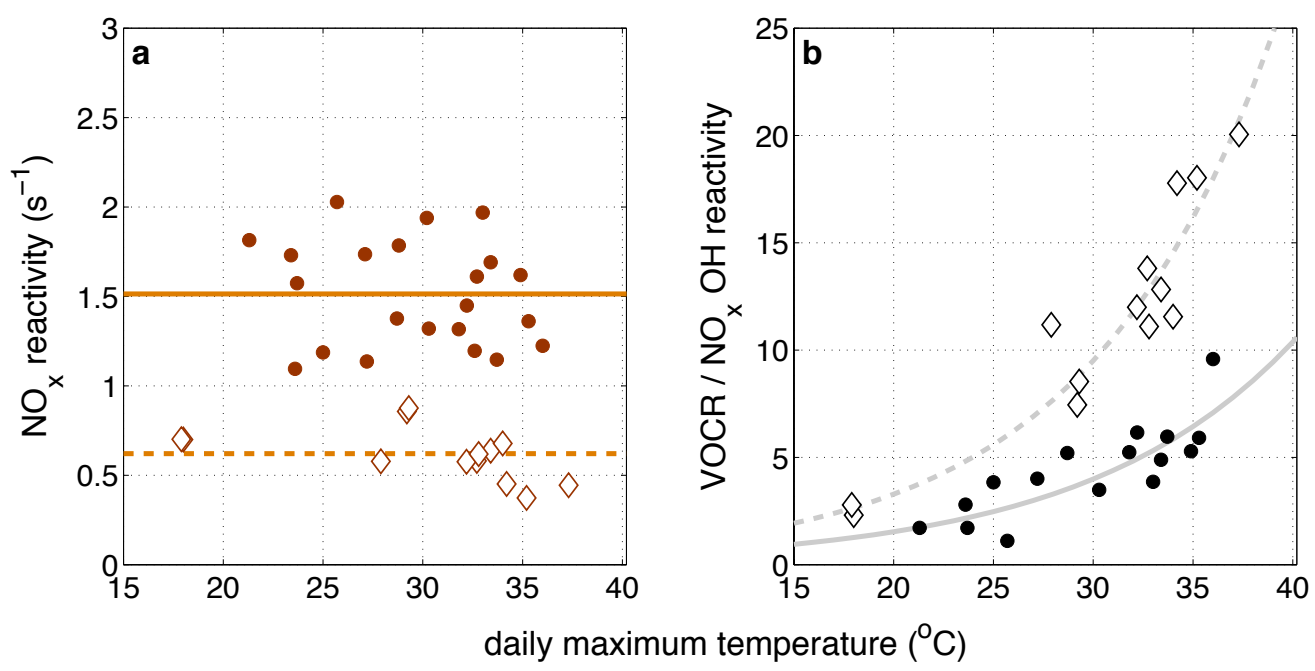

Fig. 4. (a) Daily average (10:00-14:00 LT) $\mathrm{NO}_{\mathrm{X}} \mathrm{R}\left(\mathrm{s}^{-1}\right)$ versus the daily maximum temperature $\left({ }^{\circ} \mathrm{C}\right)$ separated by weekdays (closed circles) and weekends (open diamonds). Weekdays are Tuesdays-Fridays. Weekends are Saturdays, Sundays, and Memorial Day (31 May 2010 ). Mondays and Saturdays are considered transition days, as they are influenced by carryover from the previous day. We omit Mondays for this reason but retain Saturdays to improve weekend statistics. The solid line is the weekday average value of $1.5 \mathrm{~s}^{-1}$ and the dashed line is the weekend average value of $0.6 \mathrm{~s}^{-1}$. (b) Total VOCR per unit $\mathrm{NO}_{\mathrm{x}} \mathrm{R}$ for weekdays (closed circles) and weekends (open diamond) versus the daily maximum temperature $\left({ }^{\circ} \mathrm{C}\right.$ ). The curves are exponential fits to the weekday (solid gray line) and weekend (dashed gray line) data.

Table 1. $\mathrm{PO}_{3}\left(\mathrm{ppb} \mathrm{h}^{-1}\right)$ computed with an analytical model parameterized with CalNex-SJV observations (the organic reactivity is equal to VOCR, not $\left.\Sigma_{i} \mathrm{VOCR}_{i}\right)$. Row 1: $\mathrm{PO}_{3}$ calculated at the 2010 average low $\left(24.7^{\circ} \mathrm{C}\right)$, moderate $\left(30.8^{\circ} \mathrm{C}\right)$, and high $\left(36.4^{\circ} \mathrm{C}\right)$ temperatures. Row 2: number of violations of the $8 \mathrm{~h}$ California $\mathrm{O}_{3}$ standard in Bakersfield in $2010\left(\right.$ day $^{-1}$ ) by temperature and by weekday/weekend. Uncertainties are computed as counting errors as $0.5(N)^{1 / 2} / N$, where $N$ is the total numbers of days in that temperature and day-of-week regime. Rows 3-5: $\mathrm{PO}_{3}\left(\mathrm{ppbh}^{-1}\right)$ calculated with $50 \%$ lower $\mathrm{NO}_{\mathrm{x}}$, with $50 \%$ lower temperature-independent $\Sigma_{i} \mathrm{VOCR}_{i}$, and with both $50 \%$ lower $\mathrm{NO}_{\mathrm{x}}$ and $50 \%$ lower temperature-independent $\Sigma_{i} \mathrm{VOCR}_{i}$. Also shown are the percent differences (\%) between the $2010 \mathrm{CalNex}$ constrained $\mathrm{PO}_{3}$ and that computed with the emissions reduction. $\mathrm{PO}_{3}$ is rounded to the nearest parts per billion per hour $\left(\mathrm{ppb} \mathrm{h}^{-1}\right)$. The relevant uncertainty is not in $\mathrm{PO}_{3}$ itself but in the derivative of $\mathrm{PO}_{3}$ with respect to $\mathrm{NO}_{\mathrm{x}}$.

\begin{tabular}{|c|c|c|c|c|c|c|}
\hline & \multicolumn{2}{|c|}{ Low (at $24.7^{\circ} \mathrm{C}$ ) } & \multicolumn{2}{|c|}{ Moderate (at $30.8^{\circ} \mathrm{C}$ ) } & \multicolumn{2}{|c|}{ High (at $36.4^{\circ} \mathrm{C}$ ) } \\
\hline & Weekdays & Weekends & Weekdays & Weekends & Weekdays & Weekends \\
\hline \multicolumn{7}{|l|}{ CalNex-SJV } \\
\hline $\mathrm{PO}_{3}\left(\mathrm{ppbh}^{-1}\right)$ & 10 & 12 & 18 & 15 & 26 & 15 \\
\hline \multicolumn{7}{|l|}{ Bakersfield 2010} \\
\hline Violations day $^{-1}$ & $0( \pm 0.10)$ & $0( \pm 0.17)$ & $0.22( \pm 0.09)$ & $0.25( \pm 0.11)$ & $0.76( \pm 0.07)$ & $0.43( \pm 0.10)$ \\
\hline \multicolumn{7}{|l|}{$-50 \% \mathrm{NO}_{\mathrm{x}}$} \\
\hline $\mathrm{PO}_{3}\left(\mathrm{ppbh}^{-1}\right)$ & 12 & 8 & 16 & 9 & 17 & 8 \\
\hline Impact (\%) & 26 & -31 & -12 & -42 & -33 & -48 \\
\hline \multicolumn{7}{|c|}{$-50 \%$ temperature-independent $\Sigma_{i} \mathrm{VOCR}_{i}$} \\
\hline $\mathrm{PO}_{3}\left(\mathrm{ppbh}^{-1}\right)$ & 7 & 11 & 16 & 14 & 25 & 15 \\
\hline Impact (\%) & -26 & -12 & -10 & -3 & -4 & -1 \\
\hline \multicolumn{7}{|c|}{$-50 \% \mathrm{NO}_{\mathrm{x}}$ and $-50 \%$ temperature-independent $\Sigma_{i} \mathrm{VOCR}_{i}$} \\
\hline $\mathrm{PO}_{3}\left(\mathrm{ppbh}^{-1}\right)$ & 11 & 8 & 15 & 8 & 17 & 8 \\
\hline Impact $(\%)$ & 7 & -35 & -15 & -43 & -33 & -46 \\
\hline
\end{tabular}



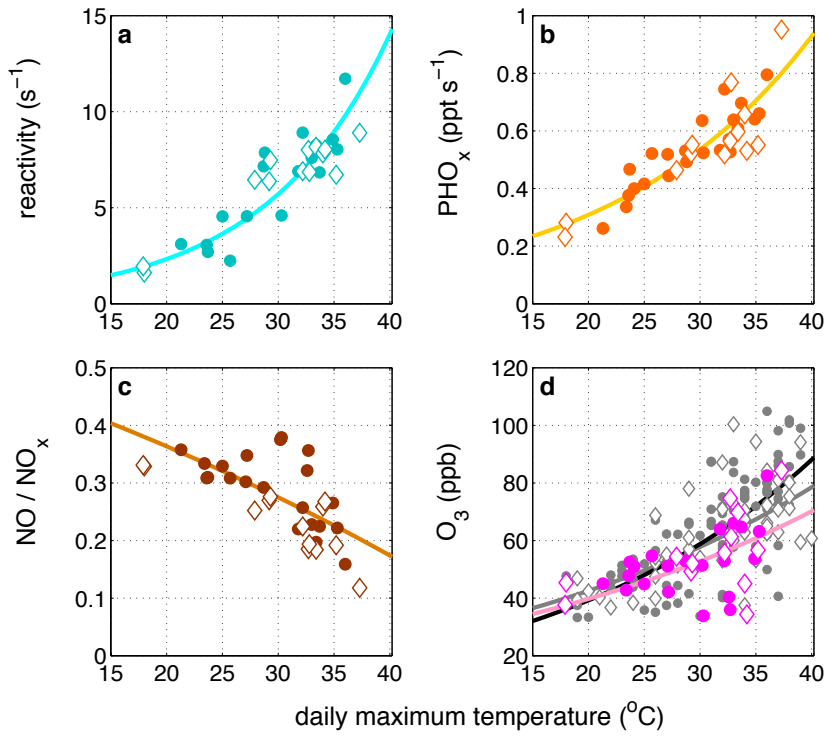

Fig. 5. (a) Total VOCR $\left(\mathrm{s}^{-1}\right.$ ) (measured $\mathrm{OH}$ reactivity minus the $\mathrm{OH}$ reactivity contributions of $\mathrm{NO}_{2}, \mathrm{NO}, \mathrm{HONO}, \mathrm{HNO}_{3}, \mathrm{NH}_{3}$, and $\mathrm{SO}_{2}$; this is equivalent to the sum of the green and blue data in Fig. 2). (b) $\mathrm{PHO}_{\mathrm{x}}\left(\mathrm{ppts}^{-1}\right.$ ). (c) $\mathrm{NO} / \mathrm{NO}_{\mathrm{x}}$. (d) $\mathrm{O}_{3}$ (ppb) during CalNex-SJV (magenta) and in Bakersfield during the entire 2010 $\mathrm{O}_{3}$ season (gray). All data are daily averages (10:00-14:00 LT) versus daily maximum temperature $\left({ }^{\circ} \mathrm{C}\right)$, are shown for weekdays (closed circles) and weekends (open diamonds), and include their exponential fits. The 2010 Bakersfield $\mathrm{O}_{3}$ data are fit separately for weekdays (solid black line) and weekends (solid gray line).

point examined in detail in Sect. 4.3). Equal weekday-toweekend percent decreases in $\mathrm{OH}$ occur alongside decreases in $\mathrm{PO}_{3}$. An equivalent reduction in the $\mathrm{OH}$-reaction removal rate of organic emissions is implied; however, enhanced weekend VOCR at high temperatures is not observed (Fig. 5a). A compensating increase in organic emissions on weekends is unlikely, as high-temperature reactivity is dominated by molecules with emission rates controlled by temperature and not by human activity (Sect. 4.1). Temperatureindependent $\Sigma_{i} \mathrm{VOCR}_{i}$ is also invariant with day of week (not shown). We are not able to definitively explain the absence of a day-of-week dependence of VOCR but suggest it is a combined effect of (a) the specific VOCR mixture in the southern SJV, (b) the limited statistics, and (c) the variability with temperature.

\subsection{Ozone production rates and the impacts of emissions controls}

Ozone production rates calculated using Eqs. (1-2) are useful for interpreting the observed frequency of $\mathrm{O}_{3}$ violations and the sensitivity of $\mathrm{PO}_{3}$ chemistry to emission changes. In Fig. 6 we map $P_{3}\left(\mathrm{ppbh}^{-1}\right)$ as a function of $\mathrm{NO}_{\mathrm{x}}$ and temperature, with the latter as a surrogate for VOCR (the fit from Fig. 5a). The average weekday (solid line) and week-

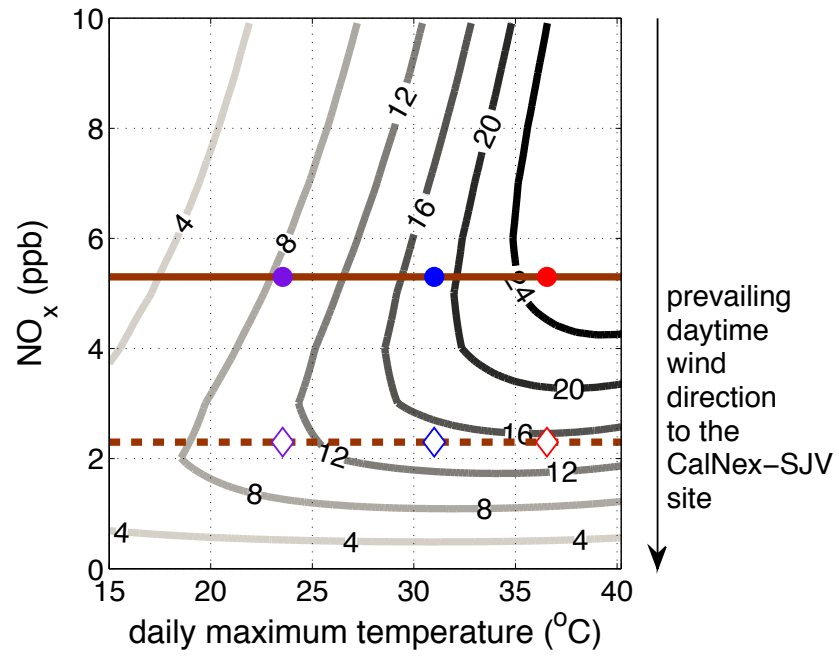

Fig. 6. $\mathrm{PO}_{3}$ at 4, 8, 12,16, 20, and $24 \mathrm{ppb} \mathrm{h}^{-1}$ as a function of $\mathrm{NO}_{\mathrm{x}}$ mixing ratio versus the daily maximum temperature $\left({ }^{\circ} \mathrm{C}\right)$. Temperature here is a surrogate for VOCR. $\mathrm{PO}_{3}$ is calculated with an analytical model constrained with the CalNex-SJV observations (see text for details). $\mathrm{NO}_{\mathrm{x}}(\mathrm{ppb})$ is shown for weekdays (solid brown line) and weekends (dashed brown line). The equivalent $\mathrm{NO}_{\mathrm{x}} \mathrm{R}$ are 1.5 and $0.6 \mathrm{~s}^{-1}$, respectively. The symbols are $\mathrm{NO}_{\mathrm{x}}$ mixing ratios at 2010-average low (purple), moderate (blue), and high (red) temperatures on weekdays (closed circles) and weekends (open diamonds) for reference. The arrow along the right-hand side represents the prevailing daytime (10:00-14:00 LT) wind direction with respect to $\mathrm{NO}_{\mathrm{x}}$ to the CalNex-SJV site, i.e., the wind travels from the higher $\mathrm{NO}_{\mathrm{X}}$ Bakersfield city center to the lower $\mathrm{NO}_{\mathrm{X}}$ measurement site.

end (dashed line) $\mathrm{NO}_{\mathrm{x}}$ mixing ratios are shown. In Table 1 we report $\mathrm{PO}_{3}$ at average low (purple), moderate (blue), and high (red) temperatures. Note the exponential form of the temperature dependence of the transition point between $\mathrm{NO}_{\mathrm{x}}$-limited and VOC-limited regimes. At low temperatures (the 2010 average), $\mathrm{PO}_{3}$ is VOC-limited and increases weekday to weekend. At moderate temperatures, weekday $\mathrm{PO}_{3}$ is VOC-limited ( 1 ppb $\mathrm{NO}_{\mathrm{x}}$ right of peak $\mathrm{PO}_{3}$ ) but decreases by $17 \%$ on weekends. At high temperatures, $\mathrm{PO}_{3}$ is at the peak with respect to $\mathrm{NO}_{\mathrm{x}}$ on weekdays and decreases by $42 \%$ on weekends, when $\mathrm{PO}_{3}$ is $\mathrm{NO}_{\mathrm{x}}$-limited.

We compare the results of our CalNex-SJV parameterized $\mathrm{PO}_{3}$ calculation to the complete Bakersfield $2010 \mathrm{O}_{3}$ record (Table 1). At low temperatures, there were no exceedances of the $8 \mathrm{~h} \mathrm{O}_{3}$ standard on either weekdays or weekends. At moderate temperatures there were $0.22 \pm 0.09$ exceedances per day on weekdays and $0.25 \pm 0.11$ exceedances per day on weekends. This is a $14 \%$ increase in the frequency of $\mathrm{O}_{3}$ exceedances weekday to weekend. At high temperatures there were $0.76 \pm 0.07$ exceedances per day on weekdays and $0.43 \pm 0.10$ exceedances per day on weekends, a $43 \%$ reduction in the frequency of violations in response the changes in emissions, particularly the $60 \% \mathrm{NO}_{\mathrm{x}}$ reduction on weekends. Uncertainties in exceedance frequency are treated as 

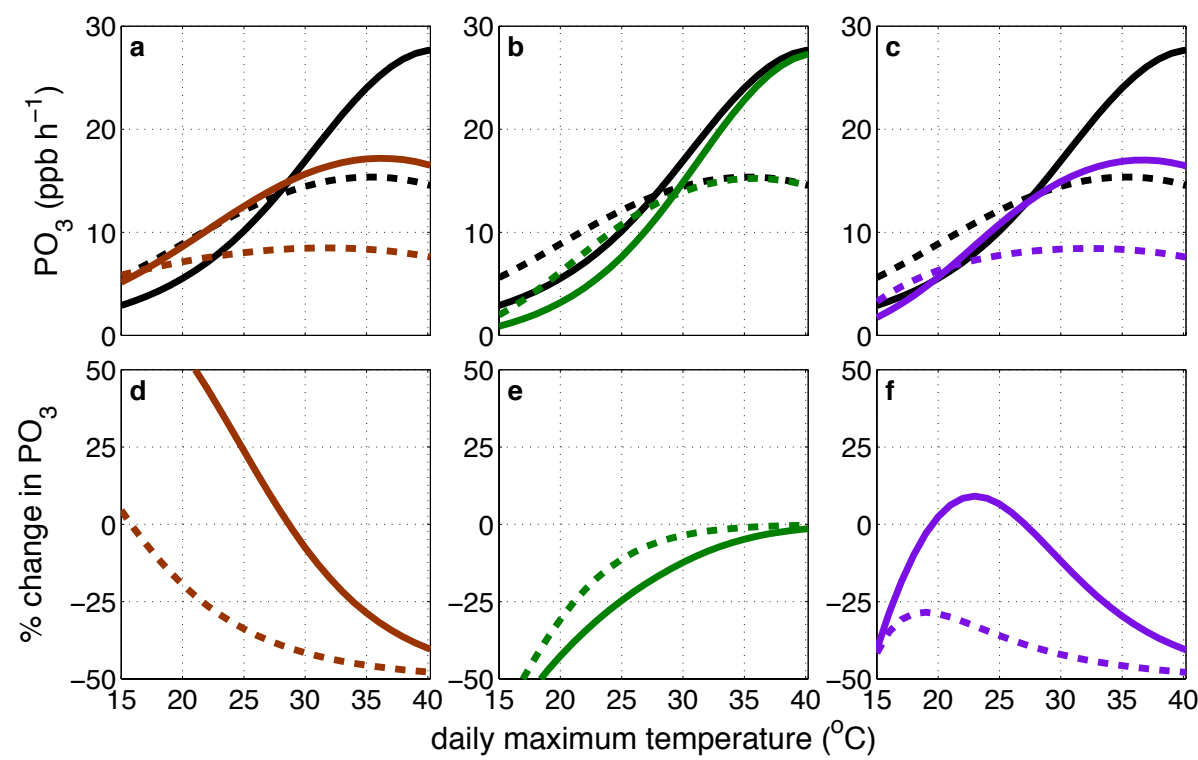

Fig. 7. (a-c) $\mathrm{PO}_{3}\left(\mathrm{ppb} \mathrm{h}^{-1}\right.$ ) on weekdays (solid line) and weekends (dashed line) versus daily maximum temperature $\left({ }^{\circ} \mathrm{C}\right)$ calculated with CalNex-SJV observations (black) and in (a) with a $50 \% \mathrm{NO}_{\mathrm{x}}$ reduction (brown), in (b) with a $50 \%$ reduction in the temperature-independent $\Sigma_{i} \operatorname{VOCR}_{i}$ (green), and in (c) with both reductions applied (purple). (d-f) the percent change between $\mathrm{PO}_{3}$ on weekdays (solid line) and weekends (dashed line) during CalNex-SJV and that computed after emission reduction versus daily maximum temperature $\left({ }^{\circ} \mathrm{C}\right)$.

counting errors as $0.5(N)^{1 / 2} / N$, with $N$ being the total numbers of days in that day-of-week and temperature bin. We see that at high temperatures, the weekday-to-weekend change in exceedance probability ( $43 \%$ ) is comparable to the $42 \%$ decrease in calculated $\mathrm{PO}_{3}$.

To make sense of the comparison at moderate temperatures and between temperature regimes requires consideration of an additional variable - that the $\mathrm{O}_{3}$ concentration is an integrated function of $\mathrm{PO}_{3}$ across the span of an urban plume. In Fig. 6, placing $\mathrm{NO}_{\mathrm{x}}$ on the $y$ axis illustrates this: directly upwind of the CalNex site was the Bakersfield city center, where $\mathrm{NO}_{\mathrm{x}}$ emissions are higher and, according to Fig. 6, $\mathrm{PO}_{3}$ is higher as well. The CalNex-SJV site was located at the plume edge (OMI satellite imagery) where gradients are steep and the upwind impact is large. At high temperatures, because weekday chemistry is near peak $\mathrm{PO}_{3}$ and because peak $P_{3}$ spans the widest range in $\mathrm{NO}_{\mathrm{x}}$ at the highest VOCR, upwind and local $\mathrm{NO}_{\mathrm{x}}$ control over production are similar, as such, $\mathrm{PO}_{3}$ and the exceedance frequency are in close agreement. At moderate temperatures, we compute that a $60 \%$ decrease in $\mathrm{NO}_{\mathrm{x}}$ is enough to transition the calculation of instantaneous $\mathrm{PO}_{3}$ to $\mathrm{NO}_{\mathrm{x}}$-limited chemistry at the CalNex-SJV site but the exceedance data suggest this is not true upwind or for the integrated $P_{3}$. Likewise, violations are approximately $40 \%$ more frequent at the equivalent $P_{3}$ at high temperatures than at moderate temperatures.

We use our constrained $\mathrm{PO}_{3}$ calculation to test the effects of possible controls on emissions (Fig. 7). We consider the following three strategies: $-50 \% \mathrm{NO}_{\mathrm{x}}$ (panels a and d), $-50 \%$ temperature-independent $\Sigma_{i} \mathrm{VOCR}_{i}$ (panels b and e), and $-50 \% \mathrm{NO}_{\mathrm{x}}$ and $-50 \%$ temperature-independent $\Sigma_{i} \operatorname{VOCR}_{i}$ (panels c and f). If temperature-independent reactivity continues to decrease at a rate of $6 \% \mathrm{yr}^{-1}$ then the $50 \%$ emission decreases are expected by $\sim 2021$. Likewise, $\mathrm{NO}_{\mathrm{x}}$ decreases in Bakersfield have been observed (from space) at approximately the same rate (Russell et al., 2012). $\mathrm{NO}_{\mathrm{x}}$ controls on heavy-duty diesel trucks that are in the implementation phase (McDonald et al., 2012) will reduce $\mathrm{NO}_{\mathrm{x}}$ emissions without concomitant VOC decreases and bring about the $-50 \% \mathrm{NO}_{\mathrm{x}}$ scenario relatively quickly. Figure 7 shows the absolute $\mathrm{PO}_{3}\left(\mathrm{ppbh}^{-1}\right)$ and percentage changes calculated during CalNex (black) on weekdays (solid line) and weekends (dashed line) for the three scenarios. We list these results at the 2010 average daily maximum temperatures in Table 1 and find our results in each case to be strongly temperature dependent.

On weekdays, a $50 \%$ reduction in $\mathrm{NO}_{\mathrm{x}}$ increases $\mathrm{PO}_{3}$ at temperatures lower than $29^{\circ} \mathrm{C}\left(\mathrm{PO}_{3}\right.$ is VOCR-limited $)$ and decreases $\mathrm{PO}_{3}$ at temperatures above $29^{\circ} \mathrm{C}\left(\mathrm{PO}_{3}\right.$ is $\mathrm{NO}_{\mathrm{x}}{ }^{-}$ limited). On weekends, a $50 \%$ reduction in $\mathrm{NO}_{\mathrm{x}}$ decreases $\mathrm{PO}_{3}$ at all temperatures $\left(>16^{\circ} \mathrm{C}\right)$ with the largest impacts at high temperatures.

A $50 \%$ decrease in the temperature-independent $\Sigma_{i} \mathrm{VOCR}_{i}$ has the largest impact at low temperatures (Fig. 7b, e). This is both because VOCR/ $\mathrm{NO}_{\mathrm{x}} \mathrm{R}$ is lowest here (Fig. 4b) and because the temperature-independent VOCR dominates at low temperatures (Fig. 3). Only at low temperatures are controls on temperature-independent $\Sigma_{i} \mathrm{VOCR}_{i}$ more effective than equivalent $\mathrm{NO}_{\mathrm{x}}$ decreases at reducing $\mathrm{PO}_{3}$. 
In the third scenario of simultaneous $50 \% \mathrm{NO}_{\mathrm{x}}$ and $50 \%$ temperature-independent $\Sigma_{i} \mathrm{VOCR}_{i}$ reductions (Fig. $7 \mathrm{c}, \mathrm{f}$ ), we find that on weekdays $\mathrm{PO}_{3}$ increases $0-9 \%$ at 20 $27^{\circ} \mathrm{C}$ and otherwise decreases at all temperatures. On weekends, $\mathrm{PO}_{3}$ decreases by at least $28 \%$ at all temperatures. The difference between simultaneous $\mathrm{NO}_{\mathrm{x}}$ and temperatureindependent $\Sigma_{i} \mathrm{VOCR}_{i}$ decreases and $\mathrm{NO}_{\mathrm{x}}$ reductions alone are minimal at moderate and high temperatures: $<2 \%$ more effective.

In summary, $\mathrm{NO}_{\mathrm{x}}$ controls will be immediately effective at decreasing $\mathrm{PO}_{3}$ under the conditions when violations of the $\mathrm{O}_{3}$ standard occur - at moderate and high temperatures. Organic emission reductions will be of limited benefit to reducing $\mathrm{PO}_{3}$ except at low temperatures, when there were zero $\mathrm{O}_{3}$ violations in 2010; this benefit will be further attenuated alongside co-occurring $\mathrm{NO}_{\mathrm{x}}$ decreases. A $50 \%$ reduction in the temperature-dependent $\Sigma_{i} \mathrm{VOCR}_{i}$ on top of the $50 \%$ reduction in temperature-independent $\Sigma_{i} \mathrm{VOCR}_{i}$ (not shown) reduces high-temperature $\left(36.4{ }^{\circ} \mathrm{C}\right) \mathrm{PO}_{3}$ by an additional $6 \%$ on weekdays and $1 \%$ on weekends. A $50 \%$ reduction in the total VOCR, including reactivity from unknown molecules, decreases $\mathrm{PO}_{3}$ at high temperatures by $25 \%$ and $6 \%$ on weekdays and weekends, respectively. However, VOCR reductions of equal effect to equivalent $\mathrm{NO}_{\mathrm{x}}$ controls require development of new approaches, as existing controls do not target the molecules dominating the reactivity at high temperatures and existing measurement networks do not observe them. Planning and executing reductions in this VOCR will likely require years of effort - a time period during which $\mathrm{NO}_{\mathrm{x}}$ controls on diesel trucks will be fully implemented and other strategies for $\mathrm{NO}_{\mathrm{x}}$ reduction could be developed with knowledge of how to monitor their success.

One consequence of the local photochemistry moving to a $\mathrm{NO}_{\mathrm{x}}$-limited regime is that in the future the temperature dependence of $\mathrm{PO}_{3}$ will diminish; at low enough $\mathrm{NO}_{\mathrm{x}}$ levels $P_{3}$ will be temperature independent, as temperature-driven increases in VOCR will not increase $P_{3}$. This is visualized in Fig. 7 in the comparison of the black solid (higher $\mathrm{NO}_{\mathrm{x}}$ emissions) and brown dashed lines (lower $\mathrm{NO}_{\mathrm{x}}$ emissions). In the future, we therefore expect less variability in $P_{3}$ and, by extension, less variability in the frequency of $\mathrm{O}_{3}$ exceedances with temperature.

\section{Summary}

Using CalNex-SJV observations of organic molecules, $\mathrm{OH}$ reactivity, $\mathrm{O}_{3}$, and nitrogen oxides we describe relationships between temperature, $\Sigma_{i} \mathrm{VOCR}_{i}$, VOCR, $\mathrm{NO}_{\mathrm{x}}$, and $\mathrm{PO}_{3}$. We find the $\Sigma_{i} \mathrm{VOCR}_{i}$ in the southern San Joaquin Valley (SJV) has a temperature-independent component with a reactivity of $2.1 \mathrm{~s}^{-1}$ and a temperature-dependent component that increases exponentially with temperature. The temperatureindependent $\Sigma_{i} \mathrm{VOCR}_{i}$ is composed of organic molecules associated with motor vehicle emissions. The known molecules contributing to the temperature-dependent VOCR are dominated by small aldehydes and alcohols; however, unidentified molecules are the largest source of reactivity at high temperatures. The $\mathrm{OH}$ reactivity of $\mathrm{NO}_{\mathrm{x}}$ is temperature independent and decreases by $\sim 60 \%$ from weekdays to weekends.

We compute $\mathrm{PO}_{3}$ using an analytical model constrained by the CalNex-SJV measurements. In response to the observed $\mathrm{NO}_{\mathrm{x}}$ decreases (at $\sim$ constant VOCR) occurring on weekends, we calculate that $\mathrm{PO}_{3}$ increases at low temperatures, decreases by $17 \%$ at moderate temperatures, and decreases by $42 \%$ at high temperatures (Fig. 6). We show consistency between weekday-to-weekend percent changes in the frequency of exceedances of the California $8 \mathrm{~h} \mathrm{O}_{3}$ standard (70.4 ppb) and the constrained model predictions suggesting the results of this short-term field experiment, viewed in the framework of temperature, give insight into the entire $\mathrm{O}_{3}$ season in the southern SJV.

Using this same $\mathrm{PO}_{3}$ model we estimate the effects of possible emission control scenarios and show the impacts are variable with temperature in both sign and magnitude. We conclude that $\mathrm{NO}_{\mathrm{x}}$ reductions will be immediately and incrementally productive at reducing $\mathrm{PO}_{3}$ on weekends at moderate temperatures and on both weekdays and weekends at high temperatures, which is when exceedances are most frequent. Reductions of the temperature-independent organic reactivity will be most effective at low temperatures; however, there were no violations of the California $8 \mathrm{~h} \mathrm{O}_{3}$ standard in 2010 at these temperatures. The impact of reductions of organic emissions on $\mathrm{O}_{3}$ violations at moderate and high temperatures will be further diminished with co-occurring $\mathrm{NO}_{\mathrm{x}}$ decreases.

Acknowledgements. This work was funded by the California Air Resources Board (contract CARB 08-316) and by the National Aeronautics and Space Administration (grant NNX10AR36G). We are grateful to John Karlik, Rick Ramirez, and the entire University of California Kern County Extension for logistical support during the CalNex-SJV project. We thank David Parrish for useful comments on our manuscript. We acknowledge the California Air Resources Board and the San Joaquin Valley Unified Air Pollution Control District for the temperature and $\mathrm{O}_{3}$ data. The findings and discussions described in this paper are those of the authors and do not necessarily represent the views of our sponsors.

Edited by: A. Carlton

\section{References}

Alanis, P., Ashkan, S., Krauter, C., Campbell, S., and Hasson, A. S.: Emissions of volatile fatty acids from feed at dairy facilities, Atmos. Environ., 44, 5084-5092, doi:10.1016/j.atmosenv.2010.09.017, 2010.

Atkinson, R.: Gas-phase tropospheric chemistry of organic compounds, J. Phys. Chem. Ref. Data, 1-216, 1994. 
Atkinson, R. and Arey, J.: Atmospheric degradation of volatile organic compounds, Chem. Rev., 103, 4605-4638, doi:10.1021/cr0206420, 2003.

Atkinson, R., Baulch, D. L., Cox, R. A., Hampson, R. F., Kerr, J. A., and Troe, J.: Evaluated kinetic and photochemical data for atmospheric chemistry supplement-IV - IUPAC subcommittee on gas kinetic data evaluation for atmospheric chemistry, J. Phys. Chem. Ref. Data, 21, 1125-1568, 1992.

Atkinson, R., Baulch, D. L., Cox, R. A., Hampson, R. F., Kerr, J. A., Rossi, M. J., and Troe, J.: Evaluated kinetic and photochemical data for atmospheric chemistry: Supplement VI - IUPAC subcommittee on gas kinetic data evaluation for atmospheric chemistry, J. Phys. Chem. Ref. Data, 26, 1329-1499, 1997.

Atkinson, R., Baulch, D. L., Cox, R. A., Crowley, J. N., Hampson, R. F. Jr., Kerr, J. A., Rossi, M. J., and Troe, J., in: Summary of evaluated kinetic and photochemical data for atmospheric chemistry, Carver, G. D., and Cox, R. A., (Eds.): IUPAC Subcommittee on Gas Kinetic Evaluation for Atmospheric Chemistry, University of Cambridge, Cambridge, 1-56, 2001.

Atkinson, R., Baulch, D. L., Cox, R. A., Crowley, J. N., Hampson, R. F., Hynes, R. G., Jenkin, M. E., Rossi, M. J., and Troe, J.: Evaluated kinetic and photochemical data for atmospheric chemistry: Volume I - gas phase reactions of $\mathrm{O}_{\mathrm{x}}, \mathrm{HO}_{\mathrm{x}}, \mathrm{NO}_{\mathrm{x}}$ and $\mathrm{SO}_{\mathrm{x}}$ species, Atmos. Chem. Phys., 4, 1461-1738, doi:10.5194/acp-41461-2004, 2004.

Bishop, G. A. and Stedman, D. H.: A decade of on-road emissions measurements, Environ. Sci. Technol., 42, 1651-1656, doi:10.1021/es702413b, 2008.

Calvert, J. G., Atkinson, R., Becker, K. H., Kamens, R. M., Seinfeld, J. H., Wallington, T. J., and Yarwood, G.: The mechanism of atmospheric oxidation of aromatic hydrocarbons, Oxford University Press, New York, NY, 95, 2002.

Cox, P., Delao, A., Komorniczak, A., and Weller, R.: The California almanac of emissions and air quality, California Air Resources Board, Sacramento, CA, 2009.

Crounse, J. D., McKinney, K. A., Kwan, A. J., and Wennberg, P. O.: Measurement of gas-phase hydroperoxides by chemical ionization mass spectrometry, Anal. Chem., 78, 6726-6732, doi:10.1021/ac0604235, 2006.

Day, D. A., Wooldridge, P. J., Dillon, M. B., Thornton, J. A., and Cohen, R. C.: A thermal dissociation laser-induced fluorescence instrument for in situ detection of $\mathrm{NO}_{2}$, peroxy nitrates, alkyl nitrates, and $\mathrm{HNO}_{3}$, J. Geophys. Res.-Atmos., 107, 4046, doi:10.1029/2001JD000779, 2002.

de Gouw, J. A., Gilman, J. B., Borbon, A., Warneke, C., Kuster, W. C., Goldan, P. D. Holloway, J. S., Peischl, J., Ryerson, T. B., Parrish, D. D., Gentner, D. R., Goldstein, A. H., and Harley, R. A.: Increasing atmospheric burden of ethanol in the United States, Geophys. Res. Lett., 39, L15803, doi:10.1029/2012GL052109, 2012.

Di Carlo, P., Brune, W. H., Martinez, M., Harder, H., Lesher, R., Ren, X. R., Thornberry, T., Carroll, M. A., Young, V., Shepson, P. B., Riemer, D., Apel, E., and Campbell, C.: Missing OH reactivity in a forest: evidence for unknown reactive biogenic VOCs, Science, 304, 722-725, doi:10.1126/science.1094392, 2004.

DiGangi, J. P., Boyle, E. S., Karl, T., Harley, P., Turnipseed, A., Kim, S., Cantrell, C., Maudlin, R. L., III, Zheng, W., Flocke, F., Hall, S. R., Ullmann, K., Nakashima, Y., Paul, J. B., Wolfe, G. M., Desai, A. R., Kajii, Y., Guenther, A., and Keutsch, F. N.:
First direct measurements of formaldehyde flux via eddy covariance: implications for missing in-canopy formaldehyde sources, Atmos. Chem. Phys., 11, 10565-10578, doi:10.5194/acp-1110565-2011, 2011.

Dillon, T. J., Holscher, D., Sivakumaran, V., Horowitz, A., and Crowley, J. N.: Kinetics of the reactions of HO with methanol (210-351 K) and with ethanol (216-368 K), Phys. Chem. Chem. Phys., 7, 349-355, doi:10.1039/b413961e, 2005.

Fares, S., Gentner, D. R., Park, J.-H., Ormeño, E., Karlik, J., and Goldstein, A. H.: Biogenic emissions from Citrus species in California, Atmos. Environ., 45, 4557-4568, doi:10.1016/j.atmosenv.2011.05.066, 2011.

Fares, S., Park, J.-H., Gentner, D. R., Weber, R., Ormeño, E., Karlik, J., and Goldstein, A. H.: Seasonal cycles of biogenic volatile organic compound fluxes and concentrations in a California citrus orchard, Atmos. Chem. Phys., 12, 9865-9880, doi:10.5194/acp12-9865-2012, 2012.

Farmer, D. K., Perring, A. E., Wooldridge, P. J., Blake, D. R., Baker, A., Meinardi, S., Huey, L. G., Tanner, D., Vargas, O., and Cohen, R. C.: Impact of organic nitrates on urban ozone production, Atmos. Chem. Phys., 11, 4085-4094, doi:10.5194/acp-11-40852011, 2011.

Galbally, I. E. and Kirstine, W.: The production of methanol by flowering plants and the global cycle of methanol, J. Atmos. Chem., 43, 195-229, doi:10.1023/A:1020684815474, 2002.

Gentner, D. R., Harley, R. A., Miller, A. M., and Goldstein, A. H.: Diurnal and seasonal variability of gasoline-related volatile organic compound emissions in Riverside, California, Environ. Sci. Technol., 43, 4247-4252, doi:10.1021/es9006228, 2009.

Gentner, D. R., Isaacman, G., Worton, D. R., Chan, A. W. H., Dallmann, T. R., Davis, L., Liu, S., Day, D. A., Russell, L. M., Wilson, K. R., Weber, R., Guha, A., Harley, R. A., and Goldstein A. H.: Elucidating secondary organic aerosol from diesel and gasoline vehicles through detailed characterization of organic carbon emissions, P. Natl. Acad. Sci., 45, 18318-18323, doi:10.1073/pnas.1212272109, 2012.

Gentner, D. R., Ford, T. B., Guha, A., Boulanger, K., Brioude, J., Angevine, W. M., de Gouw, J. A., Warneke, C., Gilman, J. B., Ryerson, T. B., Peischl, J., Meinardi, S., Blake, D. R., Atlas, E., Lonneman, W. A., Kleindienst, T. E., Beaver, M. R., Clair, J. M. St., Wennberg, P. O., VandenBoer, T. C., Markovic, M. Z., Murphy, J. G., Harley, R. A., and Goldstein, A. H.: Emissions of organic carbon and methane from petroleum and dairy operations in California's San Joaquin Valley, Atmos. Chem. Phys. Discuss., 13, 28225-28278, doi:10.5194/acpd-13-28225-2013, 2013 a.

Gentner, D. R., Ormeño, E., Fares, S., Ford, T. B., Weber, R., Park, J.-H., Brioude, J., Angevine, W. M., Karlik, J. F., and Goldstein, A. H.: Emissions of biogenic gas-phase organic carbon from agricultural crops and their potential implications of air quality, in preparation for Atmos. Chem. Phys. Discuss., 2013b.

Guenther, A. B., Zimmerman, P. R., Harley, P. C., Monson, R. K., and Fall, R.: Isoprene and monoterpene emission rate variability: model evaluations and sensitivity analyses, J. Geophys. Res., 98, 12609-12617, doi:10.1029/93JD00527, 1993.

Harley, R. A., Hooper, D. S., Kean, A. J., Kirchstetter, T. W., Hesson, J. M., Balberan, N. T., Stevenson, E. D., and Kendall, G. R.: Effects of reformulated gasoline and motor vehicle fleet turnover on emissions and ambient concentrations of benzene, Environ. Sci. Technol., 40, 5084-5088, doi:10.1021/es0604820, 2006. 
Hottle, J. R., Huisman, A. J., Digangi, J. P., Kammrath, A., Galloway, M. M., Coens, K. L., and Keutsch, F. N.: A laser induced fluorescence-based instrument for in-situ measurements of atmospheric formaldehyde, Environ. Sci. Technol., 43, 790-795, doi:10.1021/es801621f, 2009.

Howard, C. J., Kumar, A., Malkina, I., Mitloehner, F., Green, P. G., Flocchini, R. G., and Kleeman, M. J.: Reactive organic gas emissions from livestock feed contribute significantly to ozone production in Central California, Environ. Sci. Technol., 44, 23092314, doi:10.1021/es902864u, 2010a.

Howard, C. J., Kumar, A., Mitloehner, F., Stackhouse, K., Green, P. G., Flocchini, R. G., and Kleeman, M. J.: Direct measurements of the ozone formation potential from livestock and poultry waste emissions, Environ. Sci. Technol., 44, 2292-2298, doi:10.1021/es901916b, 2010b.

Hu, J. L., Howard, C. J., Mitloehner, F., Green, P. G., and Kleeman, M. J.: Mobile source and livestock feed contributions to regional ozone formation in Central California, Environ. Sci. Technol., 46, 2781-2789, doi:10.1021/es203369p, 2012.

Huisman, A. J., Hottle, J. R., Coens, K. L., DiGangi, J. P., Galloway, M. M., Kammrath, A., and Keutsch, F. N.: Laserinduced phosphorescence for the in situ detection of glyoxal at part per trillion mixing ratios, Anal. Chem., 80, 5884-5891, doi:10.1021/ac800407b, 2008.

Huisman, A. J., Hottle, J. R., Galloway, M. M., DiGangi, J. P., Coens, K. L., Choi, W., Faloona, I. C., Gilman, J. B., Kuster, W. C., de Gouw, J., Bouvier-Brown, N. C., Goldstein, A. H., LaFranchi, B. W., Cohen, R. C., Wolfe, G. M., Thornton, J. A., Docherty, K. S., Farmer, D. K., Cubison, M. J., Jimenez, J. L., Mao, J., Brune, W. H., and Keutsch, F. N.: Photochemical modeling of glyoxal at a rural site: observations and analysis from BEARPEX 2007, Atmos. Chem. Phys., 11, 8883-8897, doi:10.5194/acp-11-88832011, 2011.

Karl, T., Guenther, A., Lindinger, C., Jordan, A., Fall, R., and Lindinger, W.: Eddy covariance measurements of oxygenated volatile organic compound fluxes from crop harvesting using a redesigned proton-transfer-reaction mass spectrometer, J. Geophys. Res.-Atmos., 106, 24157-24167, doi:10.1029/2000JD000112, 2001.

Kirchstetter, T. W., Singer, B. C., Harley, R. A., Kendall, G. R., and Hesson, J. M.: Impact of California reformulated gasoline on motor vehicle emissions. 2. Volatile organic compound speciation and reactivity, Environ. Sci. Technol., 33, 329-336, doi:10.1021/es980374g, 1999a.

Kirchstetter, T. W., Singer, B. C., Harley, R. A., Kendall, G. R., and Traverse, M.: Impact of California reformulated gasoline on motor vehicle emissions. 1. Mass emission rates, Environ. Sci. Technol., 33, 318-328, doi:10.1021/es9803714, 1999b.

Kovacs, T. A., Brune, W. H., Harder, H., Martinez, M., Simpas, J. B., Frost, G. J., Williams, E., Jobson, T., Stroud, C., Young, V., Fried, A., and Wert, B.: Direct measurements of urban OH reactivity during Nashville SOS in summer 1999, J. Environ. Monitor., 5, 68-74, doi:10.1039/b204339d, 2003.

LaFranchi, B. W., Wolfe, G. M., Thornton, J. A., Harrold, S. A., Browne, E. C., Min, K. E., Wooldridge, P. J., Gilman, J. B., Kuster, W. C., Goldan, P. D., de Gouw, J. A., McKay, M., Goldstein, A. H., Ren, X., Mao, J., and Cohen, R. C.: Closing the peroxy acetyl nitrate budget: observations of acyl peroxy nitrates
(PAN, PPN, and MPAN) during BEARPEX 2007, Atmos. Chem. Phys., 9, 7623-7641, doi:10.5194/acp-9-7623-2009, 2009.

LaFranchi, B. W., Goldstein, A. H., and Cohen, R. C.: Observations of the temperature dependent response of ozone to $\mathrm{NO}_{\mathrm{X}}$ reductions in the Sacramento, CA urban plume, Atmos. Chem. Phys., 11, 6945-6960, doi:10.5194/acp-11-6945-2011, 2011.

Lou, S., Holland, F., Rohrer, F., Lu, K., Bohn, B., Brauers, T., Chang, C. C., Fuchs, H., Haseler, R., Kita, K., Kondo, Y., Li, X., Shao, M., Zeng, L., Wahner, A., Zhang, Y., Wang, W., and Hofzumahaus, A.: Atmospheric $\mathrm{OH}$ reactivities in the Pearl River Delta - China in summer 2006: measurement and model results, Atmos. Chem. Phys., 10, 11243-11260, doi:10.5194/acp-10-11243-2010, 2010.

Madronich, S.: Photodissociation in the atmosphere. 1. Actinic flux and the effects of ground reflections and clouds, J. Geophys. Res.-Atmos., 92, 9740-9752, doi:10.1029/JD092iD08p09740, 1987.

Malkina, I. L., Kumar, A., Green, P. G., and Mitloehner, F. M.: Identification and quantitation of volatile organic compounds emitted from dairy silages and other feedstuffs, J. Environ. Qual., 40, 2836, doi:10.2134/jeq2010.0302, 2011.

Mao, J., Ren, X., Zhang, L., Van Duin, D. M., Cohen, R. C., Park, J. H., Goldstein, A. H., Paulot, F., Beaver, M. R., Crounse, J. D., Wennberg, P. O., DiGangi, J. P., Henry, S. B., Keutsch, F. N., Park, C., Schade, G. W., Wolfe, G. M., Thornton, J. A., and Brune, W. H.: Insights into hydroxyl measurements and atmospheric oxidation in a California forest, Atmos. Chem. Phys., 12, 8009-8020, doi:10.5194/acp-12-8009-2012, 2012.

Markovic, M. Z., VandenBoer, T. C., and Murphy J. G.: Characterization and optimization of an online system for the simultaneous measurement of atmospheric water-soluble constituents in the gas and particle phases, J. Environ. Monit., 14, 1872-1884, doi:10.1039/c2em00004k, 2012.

Master Chemical Mechanism, MCM v3.2: http://mcm.leeds.ac.uk/ MCM/home.htt (last access: 10 January 2014), 2014.

McDonald, B. C., Dallmann, T. R., Martin, E. W., and Harley, R. A.: Long-term trends in nitrogen oxide emissions from motor vehicles at national, state, and air basin scales, J. Geophys. Res.Atmos., 117, D00V18, doi:10.1029/2012JD018304, 2012.

Mielke, L. H., Furgeson, A., and Osthoff, H. D.: Observation of $\mathrm{CINO}_{2}$ in a mid-continental urban environment, Environ. Sci. Technol., 45, 8889-8896, doi:10.1021/es201955u, 2011.

Min, K.-E., Pusede, S. E., Browne, E. C., LaFranchi, B. W., Wooldridge, P. J., and Cohen, R. C.: Eddy covariance fluxes and vertical concentration gradient measurements of $\mathrm{NO}$ and $\mathrm{NO}_{2}$ over a ponderosa pine ecosystem: observational evidence for canopy removal of $\mathrm{NO}_{\mathrm{x}}$, Atmos. Chem. Phys. Discuss., 13, 12437-12484, doi:10.5194/acpd-13-12437-2013, 2013.

Mollner, A. K., Valluvadasan, S., Feng, L., Sprague, M. K., Okumura, M., Milligan, D. B., Bloss, W. J., Sander, S. P., Martien, P. T., Harley, R. A., McCoy, A. B., and Carter, W. P. L.: Rate of gas phase association of hydroxyl radical and nitrogen dioxide, Science, 330, 646-649, doi:10.1126/science.1193030, 2010.

Murphy, J. G., Day, D. A., Cleary, P. A., Wooldridge, P. J., Millet, D. B., Goldstein, A. H., and Cohen, R. C.: The weekend effect within and downwind of Sacramento - Part 1: Observations of ozone, nitrogen oxides, and VOC reactivity, Atmos. Chem. Phys., 7, 5327-5339, doi:10.5194/acp-7-5327-2007, 2007. 
Ormeño, E., Gentner, D. R., Fares, S., Karlik, J., Park, J. H., and Goldstein, A. H.: Sesquiterpenoid emissions from agricultural crops: correlations to monoterpenoid emissions and leaf terpene content, Environ. Sci. Technol., 44, 3758-3764, doi:0.1021/es903674m, 2010.

Osthoff, H. D., Roberts, J. M., Ravishankara, A. R., Williams, E. J., Lerner, B. M., Sommariva, R., Bates, T. S., Coffman, D., Quinn, P. K., Dibb, J. E., Stark, H., Burkholder, J. B., Talukdar, R. K., Meagher, J., Fehsenfeld, F. C., and Brown, S. S.: High levels of nitryl chloride in the polluted subtropical marine boundary layer, Nat. Geosci., 1, 324-328, doi:10.1038/ngeo177, 2008.

Park, J. H., Goldstein, A. H., Timkovsky, J., Fares, S., Weber, R., Karlik, J., and Holzinger, R.: Active atmosphere-ecosystem exchange of the vast majority of detected volitile organic compounds, Science, 341, 643-647, doi:10.1126/science.1235053, $2013 \mathrm{a}$.

Park, J. H., Goldstein, A. H., Timkovsky, J., Fares, S., Weber, R., Karlik, J., and Holzinger, R.: Eddy covariance emission and deposition flux measurements using proton transfer reaction - time of flight - mass spectrometry (PTR-TOF-MS): comparison with PTR-MS measured vertical gradients and fluxes, Atmos. Chem. Phys., 13, 1439-1456, doi:10.5194/acp-13-1439-2013, 2013 b.

Parrish, D. D.: Critical evaluation of US on-road vehicle emission inventories, Atmos. Environ., 40, 2288-2300, doi:10.1016/j.atmosenv.2005.11.033, 2006.

Parrish, D. D., Trainer, M., Hereid, D., Williams, E. J., Olszyna, K. J., Harley, R. A., Meagher, J. F., and Fehsenfeld, F. C.: Decadal change in carbon monoxide to nitrogen oxide ratio in US vehicular emissions, J. Geophys. Res.-Atmos., 107, 4140, doi:10.1029/2001JC000720, 2002.

Perring, A. E., Pusede, S. E., and Cohen, R. C.: An observational perspective on the atmospheric impacts of alkyl and multifunctional nitrates on ozone and secondary organic aerosol, Chem. Rev., 113, 5848-5870, doi:10.1021/cr300520x, 2013.

Pierson, W. R., Schorran, D. E., Fujita, E. M., Sagebiel, J. C., Lawson, D. R., and Tanner, R. L.: Assessment of nontailpipe hydrocarbon emissions from motor vehicles, J. Air Waste Manage. Assoc., 49, 498-519, 1999.

Pusede, S. E. and Cohen, R. C.: On the observed response of ozone to $\mathrm{NO}_{\mathrm{x}}$ and VOC reactivity reductions in San Joaquin Valley California 1995-present, Atmos. Chem. Phys., 12, 8323-8339, doi:10.5194/acp-12-8323-2012, 2012.

Ren, X., Sanders, J. E., Rajendran, A., Weber, R. J., Goldstein, A. H., Pusede, S. E., Browne, E. C., Min, K.-E., and Cohen, R. C.: A relaxed eddy accumulation system for measuring vertical fluxes of nitrous acid, Atmos. Meas. Tech., 4, 2093-2103, doi:10.5194/amt-4-2093-2011, 2011.

Russell, A. R., Valin, L. C., and Cohen, R. C.: Trends in $\mathrm{OMI} \mathrm{NO}_{2}$ observations over the United States: effects of emission control technology and the economic recession, Atmos. Chem. Phys., 12, 12197-12209, doi:10.5194/acp-12-12197-2012, 2012.

Rubin, J. I., Kean, A. J., Harley, R. A., Millet, D. B., and Goldstein, A. H.: Temperature dependence of volatile organic compound evaporative emissions from motor vehicles, J. Geophys. Res.-Atmos., 111, D03305, doi:10.1029/2005JD006458, 2006.

Ryerson, T. B., Andrews, A. E., Angevine, W. M., Bates, T. S., Brock, C. A., Cairns, B., Cohen, R. C., Cooper, O. R., de Gouw, J. A., Fehsenfeld, F. C., Ferrare, R. A., Fischer, M. L., Flagan, R. C., Goldstein, A. H., Hair, J. W., Hardesty, R. M., Hostetler, C.
A., Jimenez, J. L., Langford, A. O., McCauley, E., McKeen, S. A., Molina, L. T., Nenes, A., Oltmans, S. J., Parrish, D. D., Pederson, J. R., Pierce, R. B., Prather, K., Quinn, P. K., Seinfeld, J. H., Senff, C. J., Sorooshian, A., Stutz, J., Surratt, J. D., Trainer, M., Volkamer, R., Williams, E. J., and Wofsy, S. C.: The 2010 California Research at the Nexus of Air Quality and Climate Change (CalNex) field study, J. Geophys. Res.- Atmos., 118, 5830-5866, doi:10.1002/jgrd.50331, 2013.

Sander, S. P., Friedl, R. R., Golden, D. M., Kurylo, M. J., Huie, R. E., Orkin, V. L., Moortgat, G. K., Ravishankara, A. R., Kolb, C. E., Molina, M. J., and Finlayson-Pitts, B. J.: Chemical kinetics and photochemical data for use in atmospheric studies, Evaluation No. 14, JPL Publication 02-25, Jet Propulsion Laboratory, Pasadena, http://jpldataeval.jpl.nasa.gov/pdf/JPL_02-25_ rev02.pdf (last access: 1 October 2011), 2003.

Schade, G. W. and Goldstein, A. H.: Fluxes of oxygenated volatile organic compounds from a ponderosa pine plantation, J. Geophys. Res.-Atmos., 106, 3111-3123, doi:10.1029/2000JD900592, 2001.

Shaw, S. L., Mitloehner, F. M., Jackson, W., Depeters, E. J., Fadel, J. G., Robinson, P. H., Holzinger, R., and Goldstein, A. H.: Volatile organic compound emissions from dairy cows and their waste as measured by proton-transfer-reaction mass spectrometry, Environ. Sci. Technol., 41, 1310-1316, doi:10.1021/es061475e, 2007.

Sprengnether, M. M., Demerjian, K. L., Dransfield, T. J., Clarke, J. S., Anderson, J. G., and Donahue, N. M.: Rate constants of nine C6-C9 alkanes with $\mathrm{OH}$ from 230 to $379 \mathrm{~K}$ : chemical tracers for OH, J. Phys. Chem. A, 113, 5030-5038, doi:10.1021/jp810412m, 2009.

Steiner, A. L., Cohen, R. C., Harley, R. A., Tonse, S., Millet, D. B., Schade, G. W., and Goldstein, A. H.: VOC reactivity in central California: comparing an air quality model to ground-based measurements, Atmos. Chem. Phys., 8, 351-368, doi:10.5194/acp-8351-2008, 2008.

Thornton, J. A., Wooldridge, P. J., and Cohen, R. C.: Atmospheric $\mathrm{NO}_{2}$ : In situ laser-induced fluorescence detection at parts per trillion mixing ratios, Anal. Chem., 72, 528-539, doi:10.1021/ac9908905, 2000.

Thornton, J. A., Kercher, J. P., Riedel, T. P., Wagner, N. L., Cozic, J., Holloway, J. S., Dube, W. P., Wolfe, G. M., Quinn, P. K., Middlebrook, A. M., Alexander, B., and Brown, S. S.: A large atomic chlorine source inferred from mid-continental reactive nitrogen chemistry, Nature, 464, 271-274, doi:10.1038/nature08905, 2010 .

VandenBoer, T. C., Markovic, M. Z., Sanders, J. E., Ren, X., Pusede, S. E., Rollins, A. W., Browne, E. C., Cohen, R. C., Weber, R. J., Goldstein, A. H., Brune, W. H., and Murphy, J. G.: Evidence for a nitrous acid (HONO) reservoir at the ground surface in Bakersfield, CA during CalNex 2010, submitted to J. Geophys. Res., 2013.

Veefkind, J. P., de Haan, J. F., Brinksma, E. J., Kroon, M., and Levelt, P. F.: Total ozone from the Ozone Monitoring Instrument (OMI) using the DOAS technique, IEEE Trans. Geo. Rem. Sens., 44, 5, 1239-1244, doi:10.1109/TGRS.2006.871204, 2006.

Wolfe, G. M., Thornton, J. A., Yatavelli, R. L. N., McKay, M., Goldstein, A. H., LaFranchi, B., Min, K. E., and Cohen, R. C.: Eddy covariance fluxes of acyl peroxy nitrates (PAN, PPN and MPAN) 
above a Ponderosa pine forest, Atmos. Chem. Phys., 9, 615-634, doi:10.5194/acp-9-615-2009, 2009.

Yamada, T., Taylor, P. H., Goumri, A., and Marshall, P.: The reaction of $\mathrm{OH}$ with acetone and acetone-d(6) from 298 to $832 \mathrm{~K}$ : Rate coefficients and mechanism, J. Chem. Phys., 119, 1060010606, doi:10.1063/1.1619950, 2003. 


\section{Appendix A}

\section{Analytical $\mathrm{PO}_{3}$ model}

Equations (A1) and (A2) give $\mathrm{OH}$ via Eq. (A3) and by solving the quadratic equation with coefficients $a, b$, and $c$ shown in Eqs. (A4-A6).

$$
\begin{aligned}
& P \mathrm{HO}_{\mathrm{x}}=L \mathrm{HO}_{\mathrm{x}}=2 k_{\mathrm{HO}_{2}+\mathrm{HO}_{2}}\left[\mathrm{HO}_{2}\right]^{2} \\
& +2 k_{\mathrm{HO}_{2}+\mathrm{RO}_{2}}\left[\mathrm{HO}_{2}\right]\left[\mathrm{RO}_{2}\right]+2 k_{\mathrm{RO}_{2}+\mathrm{RO}_{2}}\left[\mathrm{RO}_{2}\right]^{2} \\
& +k_{\mathrm{NO}_{2}+\mathrm{OH}}\left[\mathrm{NO}_{2}\right][\mathrm{OH}]+\alpha k_{\mathrm{NO}+\mathrm{RO}_{2}}[\mathrm{NO}]\left[\mathrm{RO}_{2}\right] \\
& {\left[\mathrm{RO}_{2}\right] \sim\left[\mathrm{HO}_{2}\right]=\frac{\mathrm{VOCR}[\mathrm{OH}]}{(1-\alpha) k_{\mathrm{NO}+\mathrm{RO}_{2}}[\mathrm{NO}]}} \\
& P \mathrm{HO}_{\mathrm{x}}= \\
& \left\{k_{\mathrm{NO}_{2}+\mathrm{OH}}\left[\mathrm{NO}_{2}\right]+\alpha k_{\mathrm{NO}+\mathrm{RO}_{2}}\left(\frac{\mathrm{VOCR}}{(1-\alpha) k_{\mathrm{NO}+\mathrm{RO}_{2}}}\right)\right\} \\
& +2\left(k_{\mathrm{HO}_{2}+\mathrm{HO}_{2}}+k_{\mathrm{HO}_{2}+\mathrm{RO}_{2}}+k_{\mathrm{RO}_{2}+\mathrm{RO}_{2}}\right) \\
& \left(\frac{\mathrm{VOCR}}{(1-\alpha) k_{\mathrm{NO}+\mathrm{RO}_{2}}[\mathrm{NO}]}\right)^{2}[\mathrm{OH}]^{2} \\
& 2\left(k_{\mathrm{HO}_{2}}+\mathrm{HO}_{2}+k_{\mathrm{HO}_{2}}+\mathrm{RO}_{2}+k_{\mathrm{RO}_{2}}+\mathrm{RO}_{2}\right) \\
& \left(\frac{\mathrm{VOCR}}{(1-\alpha) k_{\mathrm{NO}+\mathrm{RO}_{2}}[\mathrm{NO}]}\right)^{2} \\
& k_{\mathrm{NO}_{2}+\mathrm{OH}}\left[\mathrm{NO}_{2}\right]+\alpha k_{\mathrm{NO}+\mathrm{RO}_{2}}\left(\frac{\mathrm{VOCR}}{(1-\alpha) k_{\mathrm{NO}+\mathrm{RO}_{2}}}\right) \\
& -P \mathrm{HO}_{\mathrm{x}}
\end{aligned}
$$

We then solve for $\mathrm{PO}_{3}=\left(k_{\mathrm{NO}+\mathrm{HO}_{2}}+k_{\mathrm{NO}+\mathrm{RO}_{2}}\right)$ $[\mathrm{NO}]\left[\mathrm{HO}_{2}\right]$. The rate expressions with units $\mathrm{cm}^{3}$ molecule $^{-1}$ $\mathrm{s}^{-1}$ are $k_{\mathrm{HO}_{2}+\mathrm{HO}_{2}}=2.2 \times 10^{-13} \exp (266 / \mathrm{T}$ ) (Atkinson et al., 1997), $\quad k_{\mathrm{HO}_{2}+\mathrm{RO}_{2}}=2.9 \times 10^{-13} \exp (1300 / \mathrm{T})$, $k_{\mathrm{RO}_{2}+\mathrm{RO}_{2}}=2.4 \times 10^{-12} \quad\left(\mathrm{MCM} \quad\right.$ v3.2), $\quad k_{\mathrm{NO}_{2}+\mathrm{OH}}=$ $9.21 \times 10^{-12}$ (this listed value is at $298 \mathrm{~K}$; we use the formulation in Mollner et al. (2010)), $k_{\mathrm{NO}+\mathrm{RO}_{2}}=2.8 \times 10^{-12} \exp (285 / \mathrm{T})$ (Atkinson et al., 2001 ), and $k_{\mathrm{NO}+\mathrm{HO}_{2}}=3.6 \times 10^{-12} \exp (270 / \mathrm{T}$ ) (Atkinson et al., 2004).

Throughout this analysis we consider instantaneous $\mathrm{PO}_{3}$ rather than net $\mathrm{PO}_{3}$ (production minus $\mathrm{O}_{3}$ chemical loss). Pathways of $\mathrm{O}_{3}$ loss are $\mathrm{O}_{3}$ photolysis to yield two $\mathrm{OH}$ (Reactions R14-R15) and reactions between $\mathrm{O}_{3}$ and $\mathrm{OH}, \mathrm{HO}_{2}$, and alkenes. Using observations of each species we find the total mean $\mathrm{O}_{3}$ loss rate to be $0.7,1.1$, and $1.4 \mathrm{ppb} \mathrm{h}^{-1}$ at low, moderate, and high temperatures, respectively. The largest contributor to $\mathrm{O}_{3}$ loss is $\mathrm{O}_{3}$ photolysis $(66 \%)$. Losses due to reactions with $\mathrm{OH}, \mathrm{HO}_{2}$, and alkenes are approximately equal in importance. Ozone's mean reactivity with $\mathrm{OH}$ is $0.08 \mathrm{~s}^{-1}$ at low, $0.1 \mathrm{~s}^{-1}$ at moderate, and $0.13 \mathrm{~s}^{-1}$ at high temperatures and is not included. 


\section{Appendix B}

\section{CalNex-SJV measurements and $\Sigma_{i} \operatorname{VOCR}_{i}$}

Table B1 lists each observation/class of observed compounds, the measurement uncertainty, analytical technique, and associated reference included in our analysis.

In Fig. B1 we show the daily averaged (10:00-14:00 LT) $\Sigma_{i} \mathrm{VOCR}_{i}$ versus daily maximum temperature for $\mathrm{C}_{1}-\mathrm{C}_{2}$ small aldehydes (panel a), $\mathrm{C}_{1}-\mathrm{C}_{2}$ alcohols (panel b), known biogenic VOCs (panel c), $\mathrm{CH}_{4}$ (panel d), temperaturedependent alkanes (generally those with $<\mathrm{C}_{10}$ ) (panel e), $\mathrm{C}_{1}-$ $\mathrm{C}_{3}$ organic acids (panel $\mathrm{f}$ ), the sum of all alkanes, alkenes, aromatics, and carbonyls observed to be independent of temperature (panel g), and $\mathrm{CO}$ (panel h). In panels a-f gray lines are the empirical exponential fits of reactivity as a function of the daily maximum temperature. In panels $\mathrm{g}-\mathrm{h}$ the gray lines are the average reactivity. Linear fits to these data give slopes that are not meaningfully different than zero. The $\mathrm{C}_{1}-\mathrm{C}_{2}$ aldehydes are $\mathrm{H}_{2} \mathrm{CO}$ and acetaldehyde (acetaldehyde's concentration was estimated, not measured; see below). The $\mathrm{C}_{1}-\mathrm{C}_{3}$ alcohols are methanol, ethanol, and isopropanol. Key molecules in the known biogenic grouping are isoprene, methacrolein, MVK, glyoxal, limonene, and $\alpha$ - and $\beta$-pinene. $\mathrm{C}_{1}-\mathrm{C}_{3}$ organic acids are formic acid, acetic acid, and propionic acid. All alkanes (panels e and h), alkenes, aromatics, and carbonyls, along with all other species included in Figs. 1 and B1 are listed in Table B2. Table B2 includes each compound's mean reactivity at low, moderate, and high daily maximum temperatures. If a temperature dependent $\mathrm{OH}$ rate expression is available we use the time varying temperature over the same time interval, not the daily maximum temperature. If no rate constant is available one is assigned by analogy to a compound with similar molecular structure, indicated with a double asterisk and an explanatory note. In order to sum the reactivities of many species, null daily average concentrations were filled using the temperature-dependent fit or average value as dictated by the observed temperature relationship. Methyl ethyl ketone is included in the temperature-dependent alkane $\Sigma_{i} \mathrm{VOCR}_{i}$, as it exhibits clear temperature dependence; this was done so as to avoid introducing another temperature-dependent grouping. In a handful of instances, individual daily average $\mathrm{VOCR}_{i}$ outliers were removed prior to computing the temperature-dependent fit or mean.
The mixing ratio of acetaldehyde is estimated assuming (a) acyl peroxy nitrate products and aldehyde sources are co-located, i.e., that PPN : propanal is equal to PAN : acetaldehyde, and (b) that acetaldehyde is the only PAN source molecule. Methacrolein, biacetyl, MVK, and methyl glyoxal are also known PAN sources. Biacetyl, MVK, and methyl glyoxal were not measured during CalNex-SJV, so to test this second assumption, we approximated their concentrations via ratios to methacrolein, as observed during the Biosphere Effects on AeRosol and Photochemistry Experiment (BEARPEX) (LaFranchi et al., 2009), which took place 15 June-31 July 2007 at a site located $\sim 3 \mathrm{~h}$ downwind from an isoprene source region. Using the calculated acetaldehyde (Fig. B1a), approximated biacetyl, MVK, and methyl glyoxal, and the measured methacrolein we find acetaldehyde to be $\sim 80 \%$ of the PAN source (compared to $<40 \%$ at $30{ }^{\circ} \mathrm{C}$ at the BEARPEX site). The dominance of acetaldehyde to PAN formation is not unexpected in the southern SVJ given the low $\mathrm{VOCR}_{\text {isoprene }}$ and $\mathrm{VOCR}_{\text {methacrolein. Alterna- }}$ tively, acetaldehyde can be calculated assuming steady state relationships with PAN, $\mathrm{HO}_{2}, \mathrm{RO}_{2}, \mathrm{NO}$, and $\mathrm{NO}_{2}$. We find this approach yields an estimated $\mathrm{VOCR}_{\text {acealdehyde }}$ that is $\sim 3$ times greater than the one we use in this analysis but with the same temperature dependence as we report. The larger acetaldehyde value would reduce the inferred missing VOCR by $\sim 20 \%$ but would not affect any other conclusion in this analysis.

MVK is estimated as 3 times the methacrolein concentration. This is the same ratio of MVK to methacrolein observed during BEARPEX-2007 (LaFranchi et al., 2009). We do not include an estimate for second-generation isoprene oxidation products. Due to the low levels of isoprene and methacrolein we expect second-generation oxidation product concentrations to also be small.

Ethane and benzene were estimated via observed relationships with propane and toluene, respectively, using the PAMS data record (Appendix C). 
Table B1. Species, measurement accuracy, analytical technique, and reference for each CalNex-SJV observation included in our analysis. Many species are measured with higher precision than accuracy. See original references for details. All CalNex data are accessible to the public at http://www.esrl.noaa.gov/csd/groups/csd7/measurements/2010calnex/.

\begin{tabular}{llll}
\hline Species & Accuracy $( \pm \%)$ & Analytical technique & Reference \\
\hline VOCs & 5 & gas chromatography-mass spectrometry & Gentner et al. (2012) \\
$\mathrm{H}_{2} \mathrm{CO}$ & 30 & laser induced fluorescence (LIF) & Hottle et al. (2009); DiGangi et al. (2011) \\
$\mathrm{PAN}$ and PPN & 21 & chemical ionization mass spectrometry (CIMS) & Wolfe et al. (2009) \\
$\mathrm{C}_{1}-\mathrm{C}_{3}$ acids & 50 & CIMS & Crounse et al. (2006) \\
glyoxal & 20 & laser induced phosphorescence & Huisman et al. (2008) \\
$\mathrm{CO}$ & 0.5 & infrared (IR) absorption & \\
$\mathrm{CH}$ & 1 & IR absorption & Kovacs et al. (2003) \\
$\mathrm{OH}_{4}$ reactivity & 32 & OH decay by LIF & Thornton et al. (2000) \\
$\mathrm{NO}_{2}$ & 5 & LIF & Min et al. (2013) \\
$\mathrm{NO}$ & 7 & chemiluminescence & Markovic et al. (2012) \\
$\mathrm{NH}_{3}, \mathrm{SO}_{2}$ & 20,15 & ambient ion monitor-ion chromatography & Ren et al. (2011) \\
$\mathrm{HONO}$ & 15 & long path absorption photometry & Crounse et al. (2006) \\
$\mathrm{HNO}_{3}$ & 50 & CIMS & Day et al. (2002) \\
$\Sigma \mathrm{ANs}$ & 15 & thermal dissociation-LIF & Dasibi 1008PC $\mathrm{O}_{3}$ monitor \\
$\mathrm{O}_{3}$ & $1 \mathrm{ppb}$ & UV absorbance & Crounse et al. (2006) \\
$\mathrm{H}_{2} \mathrm{O}_{2}$ & 50 & CIMS & \\
\hline
\end{tabular}



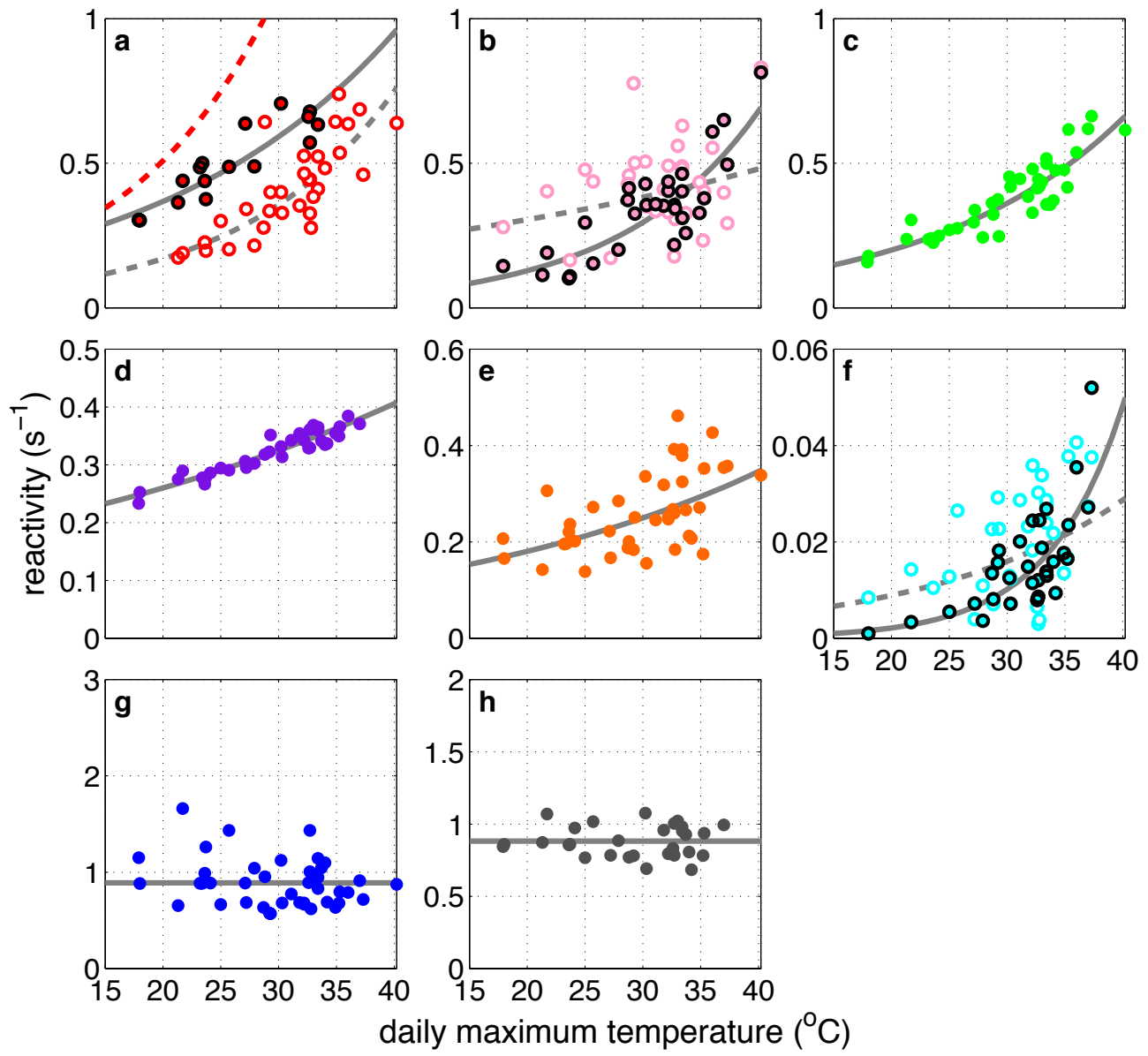

Fig. B1. Daily average $\Sigma_{i} \operatorname{VOCR}_{i}\left(\mathrm{~s}^{-1}\right)$ versus the daily maximum temperature $\left({ }^{\circ} \mathrm{C}\right)$ for $\left(\right.$ a) $\mathrm{H}_{2} \mathrm{CO}$ (closed circles with black outline) and calculated acetaldehyde (open circles), (b) methanol (closed circles with black outline) and ethanol (open circles), c) known biogenic VOCs, (d) $\mathrm{CH}_{4}$, (e) temperature-dependent alkanes, (f) formic acid (closed circles with black outline) and acetic acid (open circles), (g) all temperature-independent AVOCs, and (h) CO. Gray solid and dashed lines are empirically derived exponential fits for (a-f). The solid lines in $(\mathbf{a}, \mathbf{b}, \mathbf{f})$ are fits to the $\mathrm{C}_{1}$ molecules; the dashed lines are fits to the $\mathrm{C}_{2}$ molecules. In (g) and (h), gray lines are means. Acetaldehyde, MVK, ethane, and benzene are estimated (see Appendix B for details), otherwise $\mathrm{VOCR}_{i}$ are derived from measured concentrations. In (a), the red dashed line shows the fit to the acetaldehyde computed from steady-state relationships, as discussed in Appendix B. 
Table B2. Mean $\operatorname{VOCR}_{i}$ of all species included in $\Sigma_{i} \mathrm{VOCR}_{i} \pm 1 \sigma$, indicating the observed variability, over low (17-27 $\left.{ }^{\circ} \mathrm{C}\right)$, moderate $\left(28-33^{\circ} \mathrm{C}\right)$, and high $\left(34-45^{\circ} \mathrm{C}\right)$ daily maximum temperatures. Species are arranged by Fig. 1 grouping and listed greatest to smallest hightemperature per second. The $\mathrm{VOC}_{i}+\mathrm{OH}$ rate constants or temperature-dependent rate expressions are also listed with associated references. The concentrations of the starred species, acetaldehyde, MVK, ethane, and benzene, were estimated (Appendix B). Double starred $k_{\mathrm{OH}}$ values were estimated by analogy to compounds with similar molecular structure and these include explanatory notes.

\begin{tabular}{|c|c|c|c|c|c|}
\hline \multirow[t]{2}{*}{ Species } & \multicolumn{3}{|c|}{ Mean $( \pm 1 \sigma)$ VOCR $\left(\mathrm{s}^{-1}\right)$ by temperature } & \multirow{2}{*}{$\begin{array}{l}k \text { or } k(T) \\
\left(\mathrm{cm}^{3} \text { molecule }^{-1} \mathrm{~s}^{-1}\right)\end{array}$} & \multirow[t]{2}{*}{ Reference } \\
\hline & Low & Moderate & High & & \\
\hline \multicolumn{6}{|l|}{$\mathrm{C}_{1}-\mathrm{C}_{2}$ aldehydes } \\
\hline $\begin{array}{l}\mathrm{H}_{2} \mathrm{CO} \\
\text { acetaldehyde* }\end{array}$ & $\begin{array}{l}4.4( \pm 1.0) \times 10^{-1} \\
2.3( \pm 0.6) \times 10^{-1}\end{array}$ & $\begin{array}{l}6.5( \pm 0.5) \times 10^{-1} \\
4.1( \pm 1.0) \times 10^{-1}\end{array}$ & $\begin{array}{l}7.9( \pm 0.8) \times 10^{-1} \\
6.2( \pm 0.9) \times 10^{-1}\end{array}$ & $\begin{array}{l}1.20 \times 10^{-14} \mathrm{Texp}(287 / \mathrm{T}) \\
4.4 \times 10^{-12} \exp (365 / \mathrm{T})\end{array}$ & $\begin{array}{l}\text { (a) } \\
\text { (a) }\end{array}$ \\
\hline \multicolumn{6}{|l|}{$\mathrm{C}_{\mathbf{1}}-\mathrm{C}_{\mathbf{3}}$ alcohols } \\
\hline $\begin{array}{l}\text { methanol } \\
\text { ethanol } \\
\text { isopropanol }\end{array}$ & $\begin{array}{l}1.6( \pm 0.6) \times 10^{-1} \\
3.4( \pm 1.4) \times 10^{-1} \\
8.9( \pm 3.4) \times 10^{-3}\end{array}$ & $\begin{array}{l}3.6( \pm 0.6) \times 10^{-1} \\
4.6( \pm 1.4) \times 10^{-1} \\
9.7( \pm 3.3) \times 10^{-3}\end{array}$ & $\begin{array}{l}5.5( \pm 1.8) \times 10^{-1} \\
4.6( \pm 2.0) \times 10^{-1} \\
1.2( \pm 0.6) \times 10^{-2}\end{array}$ & $\begin{array}{l}3.82 \times 10^{-19} \mathrm{~T}^{2.4} \exp (300 / \mathrm{T}) \\
6.72 \times 10^{-18} \mathrm{~T}^{2} \exp (510 / \mathrm{T}) \\
4.03 \times 10^{-18} \mathrm{~T}^{2} \exp (792 / \mathrm{T})\end{array}$ & $\begin{array}{l}\text { (b) } \\
\text { (b) } \\
\text { (a) }\end{array}$ \\
\hline \multicolumn{6}{|l|}{ Known biogenic VOCs } \\
\hline $\begin{array}{l}\text { isoprene } \\
\text { methacrolein } \\
\text { d-limonene } \\
\text { MVK* } \\
\text { glyoxal } \\
\alpha \text {-pinene } \\
\text { d3-carene } \\
\text { sabinene } \\
\text { acetone } \\
\text { camphene } \\
\beta \text {-pinene } \\
\text { nopinone }\end{array}$ & $\begin{array}{l}9.0( \pm 3.2) \times 10^{-2} \\
6.2( \pm 0.5) \times 10^{-2} \\
2.9( \pm 0.2) \times 10^{-2} \\
3.4( \pm 1.7) \times 10^{-2} \\
1.6( \pm 0.4) \times 10^{-2} \\
2.0( \pm 1.2) \times 10^{-2} \\
1.6( \pm 1.0) \times 10^{-2} \\
5.3( \pm 3.8) \times 10^{-3} \\
1.5( \pm 0.5) \times 10^{-3} \\
2.8( \pm 0.7) \times 10^{-3} \\
2.2( \pm 1.3) \times 10^{-3} \\
6.9( \pm 2.3) \times 10^{-4}\end{array}$ & $\begin{array}{l}1.6( \pm 0.4) \times 10^{-1} \\
8.0( \pm 1.8) \times 10^{-2} \\
3.8( \pm 0.9) \times 10^{-2} \\
3.7( \pm 1.7) \times 10^{-2} \\
2.6( \pm 0.4) \times 10^{-2} \\
2.1( \pm 1.1) \times 10^{-2} \\
2.1( \pm 0.5) \times 10^{-2} \\
7.3( \pm 2.0) \times 10^{-3} \\
3.4( \pm 1.1) \times 10^{-3} \\
3.4( \pm 1.0) \times 10^{-3} \\
2.8( \pm 0.6) \times 10^{-3} \\
6.3( \pm 4.0) \times 10^{-4}\end{array}$ & $\begin{array}{l}2.4( \pm 0.5) \times 10^{-1} \\
1.2( \pm 2.6) \times 10^{-1} \\
5.7( \pm 1.3) \times 10^{-2} \\
3.8( \pm 2.0) \times 10^{-2} \\
2.9( \pm 0.7) \times 10^{-2} \\
2.4( \pm 1.1) \times 10^{-2} \\
2.2( \pm 0.5) \times 10^{-2} \\
1.0( \pm 0.2) \times 10^{-2} \\
5.8( \pm 3.7) \times 10^{-3} \\
3.9( \pm 1.1) \times 10^{-3} \\
3.4( \pm 0.6) \times 10^{-3} \\
6.0( \pm 2.4) \times 10^{-4}\end{array}$ & $\begin{array}{l}2.7 \times 10^{-11} \exp (390 / \mathrm{T}) \\
8.0 \times 10^{-12} \exp (380 / \mathrm{T}) \\
4.28 \times 10^{-11} \exp (401 / \mathrm{T}) \\
2.6 \times 10^{-12} \exp (610 / \mathrm{T}) \\
1.10 \times 10^{-11} \\
12.1 \times 10^{-12} \exp (436 / \mathrm{T}) \\
8.8 \times 10^{-11} \\
1.17 \times 10^{-10} \\
4.0 \times 10^{-24} \mathrm{~T}^{4} \exp (453 / \mathrm{T}) \\
5.3 \times 10^{-11} \\
15.5 \times 10^{-12} \exp (467 / \mathrm{T}) \\
1.5 \times 10^{-11}\end{array}$ & $\begin{array}{l}\text { (a) } \\
\text { (a) } \\
\text { (a) } \\
\text { (a) } \\
\text { (a) } \\
\text { (a) } \\
\text { (a) } \\
\text { (a) } \\
\text { (c) } \\
\text { (a) } \\
\text { (a) } \\
\text { (a) }\end{array}$ \\
\hline \multicolumn{6}{|l|}{$\mathrm{CH}_{4}$} \\
\hline $\mathrm{CH}_{4}$ & $2.8( \pm 0.2) \times 10^{-1}$ & $8.9( \pm 0.2) \times 10^{-1}$ & $3.6( \pm 0.2) \times 10^{-1}$ & $1.85 \times 10^{-20} \mathrm{~T}^{2.85} \exp (-987 / \mathrm{T})$ & (a) \\
\hline \multicolumn{6}{|l|}{ Temperature-dependent alkanes } \\
\hline $\begin{array}{l}\text { isopentane } \\
\text { propane } \\
n \text {-butane } \\
n \text {-pentane } \\
\text { 2-methylpentane and 2,3-dimethylbutane } \\
\text { methylcyclopentane } \\
n \text {-hexane } \\
\text { 3-methylpentane } \\
n \text {-heptane } \\
\text { cyclopentane } \\
\text { 2,3,4-trimethylpentane } \\
\text { ethane* } \\
\text { isooctane } \\
\text { 2,3-dimethylpentane } \\
\text { 2,4- and 2,2-dimethylpentane } \\
\text { 2,2-dimethylbutane } \\
\text { 3-methylheptane } \\
\text { 2,4-dimethylhexane } \\
\text { 2,2,5-trimethylhexane } \\
\text { 3,3-dimethylpentane } \\
\text { 2,2,3-trimethylpentane } \\
\text { 2,2-dimethylhexane } \\
\text { 2,2,5-trimethylheptane }\end{array}$ & $\begin{array}{l}3.7( \pm 0.9) \times 10^{-2} \\
5.0( \pm 2.3) \times 10^{-2} \\
3.3( \pm 1.8) \times 10^{-2} \\
2.0( \pm 0.4) \times 10^{-2} \\
1.5( \pm 0.3) \times 10^{-2} \\
1.2( \pm 0.4) \times 10^{-2} \\
7.7( \pm 2.2) \times 10^{-3} \\
6.7( \pm 1.7) \times 10^{-3} \\
5.5( \pm 2.4) \times 10^{-3} \\
4.9( \pm 1.4) \times 10^{-3} \\
6.1( \pm 2.3) \times 10^{-3} \\
5.0( \pm 2.3) \times 10^{-3} \\
4.2( \pm 2.1) \times 10^{-3} \\
4.6( \pm 2.6) \times 10^{-3} \\
1.5( \pm 0.3) \times 10^{-3} \\
1.4( \pm 0.3) \times 10^{-3} \\
1.5( \pm 0.3) \times 10^{-3} \\
1.3( \pm 0.5) \times 10^{-3} \\
1.1( \pm 0.6) \times 10^{-3} \\
6.3( \pm 3.0) \times 10^{-4} \\
4.7( \pm 3.0) \times 10^{-4} \\
1.4( \pm 0.2) \times 10^{-4} \\
1.2( \pm 0.3) \times 10^{-4}\end{array}$ & $\begin{array}{l}6.3( \pm 1.8) \times 10^{-2} \\
5.0( \pm 1.8) \times 10^{-2} \\
2.9( \pm 1.6) \times 10^{-2} \\
3.0( \pm 0.9) \times 10^{-2} \\
2.3( \pm 0.6) \times 10^{-2} \\
1.6( \pm 0.6) \times 10^{-2} \\
1.0( \pm 0.3) \times 10^{-2} \\
9.8( \pm 3.2) \times 10^{-3} \\
8.5( \pm 3.0) \times 10^{-3} \\
6.9( \pm 2.4) \times 10^{-3} \\
7.2( \pm 2.0) \times 10^{-3} \\
5.0( \pm 1.8) \times 10^{-3} \\
4.9( \pm 1.3) \times 10^{-3} \\
4.6( \pm 1.4) \times 10^{-3} \\
2.3( \pm 0.7) \times 10^{-3} \\
2.2( \pm 0.6) \times 10^{-3} \\
1.8( \pm 0.9) \times 10^{-3} \\
1.5( \pm 0.4) \times 10^{-3} \\
1.2( \pm 0.4) \times 10^{-3} \\
9.2( \pm 3.5) \times 10^{-4} \\
6.9( \pm 3.5) \times 10^{-4} \\
1.6( \pm 0.7) \times 10^{-4} \\
1.2( \pm 0.3) \times 10^{-4}\end{array}$ & $\begin{array}{l}7.2( \pm 2.2) \times 10^{-2} \\
5.9( \pm 2.1) \times 10^{-2} \\
3.6( \pm 1.5) \times 10^{-2} \\
3.3( \pm 1.0) \times 10^{-2} \\
2.5( \pm 0.8) \times 10^{-2} \\
1.7( \pm 0.5) \times 10^{-2} \\
1.1( \pm 0.3) \times 10^{-2} \\
1.1( \pm 0.3) \times 10^{-2} \\
7.9( \pm 3.0) \times 10^{-3} \\
7.8( \pm 2.7) \times 10^{-3} \\
6.4( \pm 2.3) \times 10^{-3} \\
5.9( \pm 2.1) \times 10^{-3} \\
4.7( \pm 1.4) \times 10^{-3} \\
4.4( \pm 1.5) \times 10^{-3} \\
2.4( \pm 0.7) \times 10^{-3} \\
2.4( \pm 0.7) \times 10^{-3} \\
1.9( \pm 0.9) \times 10^{-3} \\
1.4( \pm 0.5) \times 10^{-3} \\
1.1( \pm 0.4) \times 10^{-3} \\
9.0( \pm 2.9) \times 10^{-4} \\
7.4( \pm 3.4) \times 10^{-4} \\
1.8( \pm 0.4) \times 10^{-4} \\
1.2( \pm 0.4) \times 10^{-4}\end{array}$ & $\begin{array}{l}3.6 \times 10^{-12} \\
1.65 \times 10^{-17} \mathrm{~T}^{2} \exp (-87 / \mathrm{T}) \\
1.81 \times 10^{-17} \mathrm{~T}^{2} \exp (114 / \mathrm{T}) \\
2.52 \times 10^{-17} \mathrm{~T}^{2} \exp (158 / \mathrm{T}) \\
5.2 \times 10^{-12} \\
7.66 \times 10^{-12} \\
2.54 \times 10^{-14} \mathrm{Texp}(-112 / \mathrm{T}) \\
5.2 \times 10^{-12} \\
1.95 \times 10^{-17} \mathrm{~T}^{2} \exp (406 / \mathrm{T}) \\
2.73 \times 10^{-17} \mathrm{~T}^{2} \exp (214 / \mathrm{T}) \\
6.6 \times 10^{-12} \\
1.49 \times 10^{-17} \mathrm{~T}^{2} \exp (-499 / \mathrm{T}) \\
2.34 \times 10^{-17} \mathrm{~T}^{2} \exp (140 / \mathrm{T}) \\
4.77 \times 10^{-12} \\
4.77 \times 10^{-12} \\
3.37 \times 10^{-11} \exp (-809 / \mathrm{T}) \\
6.0 \times 10^{-12} \\
6.0 \times 10^{-12} \\
6.0 \times 10^{-12} \\
6.0 \times 10^{-12} \\
6.0 \times 10^{-12} \\
6.0 \times 10^{-12} \\
6.0 \times 10^{-12}\end{array}$ & $\begin{array}{l}\text { (a) } \\
\text { (a) } \\
\text { (a) } \\
\text { (a) } \\
\text { (a) }{ }^{1} \\
\text { (d) } \\
\text { (a) } \\
\text { (a) } \\
\text { (a) } \\
\text { (a) } \\
\text { (a) } \\
\text { (a) } \\
\text { (a) } \\
\text { (a) } \\
\text { (a) } \\
\text { (a) } \\
(* *)^{3} \\
(* *)^{3} \\
(* *)^{3} \\
(* *)^{3} \\
(* *)^{3} \\
(* *)^{3} \\
(* *)^{3}\end{array}$ \\
\hline \multicolumn{6}{|l|}{$\mathrm{C}_{1}-\mathrm{C}_{\mathbf{3}}$ acids } \\
\hline $\begin{array}{l}\text { acetic acid } \\
\text { formic acid } \\
\text { propionic acid }\end{array}$ & $\begin{array}{l}1.2( \pm 0.7) \times 10^{-2} \\
4.1( \pm 2.4) \times 10^{-3} \\
4.3( \pm 1.7) \times 10^{-3}\end{array}$ & $\begin{array}{l}1.9( \pm 1.0) \times 10^{-2} \\
1.5( \pm 0.6) \times 10^{-2} \\
6.3( \pm 2.6) \times 10^{-3}\end{array}$ & $\begin{array}{l}2.7( \pm 1.1) \times 10^{-2} \\
2.6( \pm 1.4) \times 10^{-2} \\
7.3( \pm 2.1) \times 10^{-3}\end{array}$ & $\begin{array}{l}8.0 \times 10^{-13} \\
4.5 \times 10^{-13} \\
1.2 \times 10^{-12}\end{array}$ & $\begin{array}{l}\text { (e) } \\
\text { (f) } \\
\text { (f) }\end{array}$ \\
\hline
\end{tabular}


Table B2. Continued.

\begin{tabular}{|c|c|c|c|c|c|}
\hline \multirow[t]{2}{*}{ Species } & \multicolumn{3}{|c|}{ Mean $( \pm 1 \sigma)$ VOCR $\left(s^{-1}\right)$ by temperature } & \multirow{2}{*}{$\begin{array}{l}k \text { or } k(T) \\
\left(\mathrm{cm}^{3} \text { molecule }{ }^{-1} \mathrm{~s}^{-1}\right)\end{array}$} & \multirow[t]{2}{*}{ Reference } \\
\hline & Low & Moderate & High & & \\
\hline \multicolumn{6}{|l|}{ Temperature-independent AVOCs } \\
\hline \multicolumn{6}{|l|}{ Temperature-independent alkanes } \\
\hline cyclohexane & $8.3( \pm 4.3) \times 10^{-3}$ & $8.5( \pm 6.1) \times 10^{-3}$ & $8.6( \pm 5.1) \times 10^{-3}$ & $3.26 \times 10^{-17} \mathrm{~T}^{2} \exp (262 / \mathrm{T})$ & (a) \\
\hline methylcyclohexane & $8.7( \pm 4.5) \times 10^{-3}$ & $7.3( \pm 2.7) \times 10^{-3}$ & $6.8( \pm 2.3) \times 10^{-3}$ & $9.64 \times 10^{-12}$ & (a) \\
\hline 3-methylhexane & $6.6( \pm 3.4) \times 10^{-3}$ & $6.1( \pm 1.9) \times 10^{-3}$ & $5.9( \pm 1.8) \times 10^{-3}$ & $6.3 \times 10^{-12}$ & (d) \\
\hline methyl ethyl ketone & $2.9( \pm 1.8) \times 10^{-3}$ & $3.7( \pm 1.7) \times 10^{-3}$ & $4.9( \pm 3.3) \times 10^{-3}$ & $1.32 \times 10^{-12} \exp (-25 / \mathrm{T})$ & (f) \\
\hline 2-methylhexane & $5.5( \pm 3.2) \times 10^{-3}$ & $5.7( \pm 1.9) \times 10^{-3}$ & $4.6( \pm 1.9) \times 10^{-3}$ & $6.69 \times 10^{-12}$ & (d) \\
\hline trans-1,3-dimethylcyclopentane & $4.5( \pm 3.1) \times 10^{-3}$ & $5.0( \pm 3.6) \times 10^{-3}$ & $4.4( \pm 2.5) \times 10^{-3}$ & $7.66 \times 10^{-12}$ & $(* *)^{4}$ \\
\hline cis-1,3-dimethylcyclopentane & $4.6( \pm 2.5) \times 10^{-3}$ & $4.3( \pm 1.6) \times 10^{-3}$ & $4.0( \pm 1.5) \times 10^{-3}$ & $7.66 \times 10^{-12}$ & $(* *)^{4}$ \\
\hline 2,3,3-trimethylpentane and 2,3-dimethylhexane & $2.6( \pm 1.6) \times 10^{-3}$ & $2.8( \pm 0.9) \times 10^{-3}$ & $2.3( \pm 1.0) \times 10^{-3}$ & $6.0 \times 10^{-12}$ & $(* *)^{3}$ \\
\hline$n$-undecane & $2.7( \pm 1.1) \times 10^{-3}$ & $2.4( \pm 1.0) \times 10^{-3}$ & $2.2( \pm 1.2) \times 10^{-3}$ & $12.3 \times 10^{-12}$ & (a) \\
\hline$n$-decane & $3.2( \pm 2.1) \times 10^{-3}$ & $2.3( \pm 0.7) \times 10^{-3}$ & $2.0( \pm 0.8) \times 10^{-3}$ & $11.0 \times 10^{-12}$ & (a) \\
\hline 2-methylheptane & $2.3( \pm 1.2) \times 10^{-3}$ & $2.1( \pm 0.6) \times 10^{-3}$ & $2.0( \pm 0.6) \times 10^{-3}$ & $6.0 \times 10^{-12}$ & $(* *)^{3}$ \\
\hline ethylcyclopentane & $2.5( \pm 1.1) \times 10^{-3}$ & $2.0( \pm 0.7) \times 10^{-3}$ & $1.9( \pm 0.7) \times 10^{-3}$ & $7.66 \times 10^{-12}$ & $(* *)^{4}$ \\
\hline$n$-dodecane & $1.6( \pm 0.7) \times 10^{-3}$ & $1.6( \pm 0.6) \times 10^{-3}$ & $1.5( \pm 0.7) \times 10^{-3}$ & $13.2 \times 10^{-12}$ & (a) \\
\hline cis,trans,cis-1,2,4-trimethylcyclopentane & $1.8( \pm 1.5) \times 10^{-3}$ & $1.7( \pm 0.5) \times 10^{-3}$ & $1.5( \pm 0.7) \times 10^{-3}$ & $8.0 \times 10^{-12}$ & $(* *)^{5}$ \\
\hline cis-1,3- and 1,1-dimethylcyclohexane & $2.1( \pm 1.3) \times 10^{-3}$ & $1.6( \pm 0.6) \times 10^{-3}$ & $1.5( \pm 0.5) \times 10^{-3}$ & $1.0 \times 10^{-11}$ & $(* *)^{6}$ \\
\hline$n$-nonane & $2.5( \pm 1.1) \times 10^{-3}$ & $1.8( \pm 0.6) \times 10^{-3}$ & $1.5( \pm 0.6) \times 10^{-3}$ & $2.53 \times 10^{-17} \mathrm{~T}^{2} \exp (436 / \mathrm{T})$ & (a) \\
\hline ethylcyclohexane & $2.0( \pm 1.2) \times 10^{-3}$ & $1.7( \pm 0.6) \times 10^{-3}$ & $1.4( \pm 0.5) \times 10^{-3}$ & $1.0 \times 10^{-11}$ & $(* *)^{6}$ \\
\hline trans-1,2-dimethylcyclohexane & $2.2( \pm 1.5) \times 10^{-3}$ & $1.7( \pm 0.6) \times 10^{-3}$ & $1.4( \pm 0.6) \times 10^{-3}$ & $1.0 \times 10^{-11}$ & $(* *)^{6}$ \\
\hline$n$-tetradecane & $1.6( \pm 0.6) \times 10^{-3}$ & $1.5( \pm 0.5) \times 10^{-3}$ & $1.3( \pm 0.4) \times 10^{-3}$ & $1.79 \times 10^{-11}$ & (a) \\
\hline$n$-tridecane & $1.8( \pm 0.5) \times 10^{-3}$ & $1.7( \pm 0.5) \times 10^{-3}$ & $1.2( \pm 0.5) \times 10^{-3}$ & $15.1 \times 10^{-12}$ & (a) \\
\hline 2,5-dimethylhexane & $1.4( \pm 0.8) \times 10^{-3}$ & $1.3( \pm 0.4) \times 10^{-3}$ & $1.2( \pm 0.4) \times 10^{-3}$ & $6.0 \times 10^{-12}$ & $(* *)^{3}$ \\
\hline trans-1,3-dimethylcyclohexane & $1.2( \pm 0.7) \times 10^{-3}$ & $9.5( \pm 2.9) \times 10^{-4}$ & $8.4( \pm 2.9) \times 10^{-4}$ & $1.0 \times 10^{-11}$ & $(* *)^{6}$ \\
\hline 2,6-dimethylheptane & $1.2( \pm 0.6) \times 10^{-3}$ & $1.0( \pm 0.4) \times 10^{-3}$ & $8.3( \pm 4.4) \times 10^{-4}$ & $6.0 \times 10^{-12}$ & $(* *)^{3}$ \\
\hline 1,1,3-trimethylcyclohexane & $1.2( \pm 0.9) \times 10^{-3}$ & $9.3( \pm 3.9) \times 10^{-4}$ & $7.8( \pm 2.8) \times 10^{-4}$ & $1.0 \times 10^{-11}$ & $(* *)^{6}$ \\
\hline 4-methylheptane & $1.6( \pm 1.3) \times 10^{-3}$ & $9.4( \pm 6.6) \times 10^{-4}$ & $7.4( \pm 2.6) \times 10^{-4}$ & $6.0 \times 10^{-12}$ & $(* *)^{3}$ \\
\hline cis-1,2-dimethylcyclohexane & $7.0( \pm 3.3) \times 10^{-4}$ & $5.6( \pm 1.5) \times 10^{-4}$ & $5.7( \pm 1.9) \times 10^{-4}$ & $1.0 \times 10^{-11}$ & $(* *)^{6}$ \\
\hline 3-methyloctane and 4-ethylheptane & $6.9( \pm 3.0) \times 10^{-4}$ & $6.2( \pm 2.0) \times 10^{-4}$ & $5.5( \pm 2.1) \times 10^{-4}$ & $6.0 \times 10^{-12}$ & $(* *)^{3}$ \\
\hline 2- and 4-methyloctane & $6.6( \pm 3.2) \times 10^{-4}$ & $5.3( \pm 1.6) \times 10^{-4}$ & $5.2( \pm 1.9) \times 10^{-4}$ & $6.0 \times 10^{-12}$ & $(* *)^{3}$ \\
\hline$n$-propylcyclopentane & $5.3( \pm 2.4) \times 10^{-4}$ & $5.2( \pm 1.7) \times 10^{-4}$ & $4.7( \pm 1.0) \times 10^{-4}$ & $8.0 \times 10^{-12}$ & $(* *)^{5}$ \\
\hline 1,1,4-trimethylcyclohexane & $5.1( \pm 5.5) \times 10^{-4}$ & $4.4( \pm 1.5) \times 10^{-4}$ & $4.4( \pm 2.9) \times 10^{-4}$ & $1.0 \times 10^{-11}$ & $(* *)^{6}$ \\
\hline cis,trans,cis-1,2,4-trimethylcyclohexane & $5.9( \pm 4.2) \times 10^{-4}$ & $4.1( \pm 1.0) \times 10^{-4}$ & $3.7( \pm 1.9) \times 10^{-4}$ & $1.0 \times 10^{-11}$ & $(* *)^{6}$ \\
\hline 3,5-dimetylheptane & $4.8( \pm 2.2) \times 10^{-4}$ & $4.1( \pm 1.3) \times 10^{-4}$ & $3.6( \pm 1.1) \times 10^{-4}$ & $6.0 \times 10^{-12}$ & $(* *)^{3}$ \\
\hline $\begin{array}{l}\text { cis,trans,trans-1,2,4- and } \\
\text { cis,cis,trans-1,3,5-trimethylhexane }\end{array}$ & $2.0( \pm 1.3) \times 10^{-4}$ & $1.8( \pm 1.1) \times 10^{-4}$ & $3.1( \pm 3.1) \times 10^{-4}$ & $1.0 \times 10^{-11}$ & $(* *)^{6}$ \\
\hline cis,cis,cis-1,3,5-trimethylcyclohexane & $3.9( \pm 2.7) \times 10^{-4}$ & $3.3( \pm 1.1) \times 10^{-4}$ & $2.9( \pm 1.7) \times 10^{-4}$ & $1.0 \times 10^{-11}$ & $(* *)^{6}$ \\
\hline isopropylcyclopentane & $2.7( \pm 1.3) \times 10^{-4}$ & $2.4( \pm 0.6) \times 10^{-4}$ & $2.4( \pm 1.3) \times 10^{-4}$ & $8.0 \times 10^{-12}$ & $(* *)^{5}$ \\
\hline 2,3-dimethylheptane & $1.7( \pm 0.6) \times 10^{-4}$ & $1.6( \pm 0.5) \times 10^{-4}$ & $1.5( \pm 0.4) \times 10^{-4}$ & $6.0 \times 10^{-12}$ & $(* *)^{3}$ \\
\hline 2,2,4-trimethylheptane & $1.5( \pm 0.6) \times 10^{-4}$ & $1.6( \pm 0.4) \times 10^{-4}$ & $1.5( \pm 0.3) \times 10^{-4}$ & $6.0 \times 10^{-12}$ & $(* *)^{3}$ \\
\hline \multicolumn{6}{|l|}{ Alkenes } \\
\hline propene & $9.0( \pm 4.7) \times 10^{-2}$ & $6.5( \pm 2.4) \times 10^{-2}$ & $5.5( \pm 1.5) \times 10^{-2}$ & $4.85 \times 10^{-12} \exp (504 / \mathrm{T})$ & (a) \\
\hline cis-2-pentene & $2.5( \pm 1.1) \times 10^{-2}$ & $3.0( \pm 0.9) \times 10^{-2}$ & $3.8( \pm 1.9) \times 10^{-2}$ & $6.50 \times 10^{-11}$ & (a) \\
\hline 1-butene and isobutene & $4.7( \pm 2.0) \times 10^{-2}$ & $3.6( \pm 1.4) \times 10^{-2}$ & $3.1( \pm 1.1) \times 10^{-2}$ & $6.55 \times 10^{-12} \exp (467 / \mathrm{T})$ & $(* *)^{7}$ \\
\hline cis-2-butene & $1.5( \pm 0.1) \times 10^{-2}$ & $1.3( \pm 0.6) \times 10^{-2}$ & $1.6( \pm 0.3) \times 10^{-2}$ & $1.1 \times 10^{-11} \exp (487 / \mathrm{T})$ & (a) \\
\hline 1-hexene & $1.8( \pm 0.7) \times 10^{-2}$ & $1.2( \pm 0.4) \times 10^{-2}$ & $1.4( \pm 0.3) \times 10^{-2}$ & $3.70 \times 10^{-11}$ & (a) \\
\hline 1-pentene & $2.4( \pm 1.4) \times 10^{-2}$ & $1.1( \pm 0.3) \times 10^{-2}$ & $1.4( \pm 0.2) \times 10^{-2}$ & $3.14 \times 10^{-11}$ & (a) \\
\hline cyclopentene & $1.3( \pm 0.7) \times 10^{-2}$ & $1.2( \pm 0.4) \times 10^{-2}$ & $1.2( \pm 0.5) \times 10^{-2}$ & $6.70 \times 10^{-11}$ & (a) \\
\hline trans-2-butene & $1.2( \pm 0.4) \times 10^{-2}$ & $1.1( \pm 0.3) \times 10^{-2}$ & $1.0( \pm 0.3) \times 10^{-2}$ & $1.01 \times 10^{-11} \exp (550 / \mathrm{T})$ & (a) \\
\hline 2-methyl-2- and cis-3-methyl-2-pentene & $3.0( \pm 1.5) \times 10^{-3}$ & $2.5( \pm 0.6) \times 10^{-3}$ & $3.2( \pm 0.8) \times 10^{-3}$ & $8.90 \times 10^{-11}$ & $(* *)^{8}$ \\
\hline 1-methylcyclohexene & $2.0( \pm 0.1) \times 10^{-3}$ & $1.7( \pm 0.5) \times 10^{-3}$ & $1.5( \pm 0.4) \times 10^{-3}$ & $8.90 \times 10^{-11}$ & $(* *)^{8}$ \\
\hline
\end{tabular}


Table B2. Continued.

\begin{tabular}{|c|c|c|c|c|c|}
\hline \multirow[t]{2}{*}{ Species } & \multicolumn{3}{|c|}{ Mean $( \pm 1 \sigma)$ VOCR $\left(\mathrm{s}^{-1}\right)$ by temperature } & \multirow{2}{*}{$\begin{array}{l}k \text { or } k(T) \\
\left(\mathrm{cm}^{3} \text { molecule }{ }^{-1} \mathrm{~s}^{-1}\right)\end{array}$} & \multirow[t]{2}{*}{ Reference } \\
\hline & Low & Moderate & High & & \\
\hline \multicolumn{6}{|l|}{ Aromatics } \\
\hline$m$ - and $p$-xylene & $3.5( \pm 2.0) \times 10^{-2}$ & $3.0( \pm 1.0) \times 10^{-2}$ & $2.5( \pm 1.1) \times 10^{-2}$ & $1.87 \times 10^{-11}$ & (a) ${ }^{9}$ \\
\hline toluene & $2.9( \pm 1.3) \times 10^{-2}$ & $2.6( \pm 0.8) \times 10^{-2}$ & $2.2( \pm 0.7) \times 10^{-2}$ & $1.18 \times 10^{-12} \exp (338 / \mathrm{T})$ & (a) \\
\hline phenol & $4.2( \pm 5.7) \times 10^{-2}$ & $1.7( \pm 0.7) \times 10^{-2}$ & $1.3( \pm 0.2) \times 10^{-2}$ & $2.70 \times 10^{-11}$ & (g) \\
\hline 1,2,4-trimethylbenzene & $1.6( \pm 1.0) \times 10^{-2}$ & $1.4( \pm 0.5) \times 10^{-2}$ & $1.2( \pm 0.5) \times 10^{-2}$ & $3.25 \times 10^{-11}$ & (a) \\
\hline 1,3,5-trimethylbenzene & $9.4( \pm 6.3) \times 10^{-3}$ & $8.4( \pm 3.5) \times 10^{-3}$ & $7.3( \pm 5.1) \times 10^{-3}$ & $5.67 \times 10^{-11}$ & (a) \\
\hline$o$-xylene & $9.2( \pm 5.1) \times 10^{-3}$ & $8.5( \pm 3.1) \times 10^{-3}$ & $7.1( \pm 3.0) \times 10^{-3}$ & $1.36 \times 10^{-11}$ & (a) \\
\hline$m$ - and $p$-ethyltoluene & $7.5( \pm 4.5) \times 10^{-3}$ & $5.8( \pm 2.2) \times 10^{-3}$ & $5.0( \pm 2.5) \times 10^{-3}$ & $1.87 \times 10^{-11}$ & $(a)^{10}$ \\
\hline ethylbenzene & $4.6( \pm 2.9) \times 10^{-3}$ & $4.1( \pm 1.4) \times 10^{-3}$ & $3.4( \pm 1.2) \times 10^{-3}$ & $7.0 \times 10^{-12}$ & (a) \\
\hline 1,2,3-trimethylbenzene & $4.8( \pm 2.3) \times 10^{-3}$ & $3.8( \pm 1.2) \times 10^{-3}$ & $3.3( \pm 1.4) \times 10^{-3}$ & $3.27 \times 10^{-11}$ & (a) \\
\hline benzene* & $2.9( \pm 1.3) \times 10^{-3}$ & $2.6( \pm 0.8) \times 10^{-3}$ & $2.2( \pm 0.7) \times 10^{-3}$ & $2.33 \times 10^{-12} \exp (-193 / \mathrm{T})$ & (a) \\
\hline$o$-ethyltoluene & $1.7( \pm 0.8) \times 10^{-3}$ & $1.4( \pm 0.5) \times 10^{-3}$ & $1.2( \pm 0.5) \times 10^{-3}$ & $1.19 \times 10^{-11}$ & (a) \\
\hline$p$-diethylbenzene & $7.0( \pm 2.4) \times 10^{-4}$ & $6.9( \pm 2.3) \times 10^{-4}$ & $6.3( \pm 3.0) \times 10^{-4}$ & $8.11 \times 10^{-12}$ & (h) \\
\hline$n$-propylbenzene & $7.5( \pm 3.1) \times 10^{-4}$ & $7.2( \pm 2.3) \times 10^{-4}$ & $6.2( \pm 2.0) \times 10^{-4}$ & $5.8 \times 10^{-12}$ & (a) \\
\hline 1-methyl-3- $n$-propyl benzene & $8.4( \pm 2.8) \times 10^{-4}$ & $8.4( \pm 3.8) \times 10^{-4}$ & $6.2( \pm 2.7) \times 10^{-4}$ & $1.0 \times 10^{-11}$ & $(* *)^{11}$ \\
\hline$m$-diethylbenzene & $5.6( \pm 2.5) \times 10^{-4}$ & $6.4( \pm 2.2) \times 10^{-4}$ & $6.2( \pm 2.2) \times 10^{-4}$ & $1.0 \times 10^{-11}$ & $(* *)^{11}$ \\
\hline$p$-cymene & $5.5( \pm 2.8) \times 10^{-4}$ & $5.6( \pm 1.5) \times 10^{-4}$ & $5.7( \pm 1.8) \times 10^{-4}$ & $1.0 \times 10^{-11}$ & $(* *)^{11}$ \\
\hline 1,3-dimethyl-4-ethylbenzene & $3.4( \pm 1.6) \times 10^{-4}$ & $2.5( \pm 0.7) \times 10^{-4}$ & $1.9( \pm 0.8) \times 10^{-4}$ & $1.0 \times 10^{-11}$ & $(* *)^{11}$ \\
\hline 1,4-dimethyl-2-ethyl benzene & $3.4( \pm 1.8) \times 10^{-4}$ & $2.2( \pm 0.7) \times 10^{-4}$ & $1.9( \pm 0.8) \times 10^{-4}$ & $1.0 \times 10^{-11}$ & $(* *)^{11}$ \\
\hline isobutylbenzene & $1.6( \pm 0.7) \times 10^{-4}$ & $1.4( \pm 0.4) \times 10^{-4}$ & $1.7( \pm 0.7) \times 10^{-4}$ & $1.0 \times 10^{-11}$ & $(* *)^{11}$ \\
\hline 1,2-dimethyl-4-ethylbenzene & $2.3( \pm 1.3) \times 10^{-4}$ & $1.9( \pm 0.5) \times 10^{-4}$ & $1.6( \pm 0.6) \times 10^{-4}$ & $1.0 \times 10^{-11}$ & $(* *)^{11}$ \\
\hline $1,2,3,5$-tetramethylbenzene & $1.7( \pm 0.5) \times 10^{-4}$ & $1.5( \pm 0.4) \times 10^{-4}$ & $1.6( \pm 0.5) \times 10^{-4}$ & $1.0 \times 10^{-11}$ & $(* *)^{11}$ \\
\hline$m$-cymene & $3.2( \pm 2.0) \times 10^{-4}$ & $1.4( \pm 0.3) \times 10^{-4}$ & $1.5( \pm 0.6) \times 10^{-4}$ & $1.0 \times 10^{-11}$ & $(* *)^{11}$ \\
\hline$n$-butylbenzene & $2.6( \pm 2.6) \times 10^{-4}$ & $1.7( \pm 0.3) \times 10^{-4}$ & $1.5( \pm 0.5) \times 10^{-4}$ & $1.0 \times 10^{-11}$ & $(* *)^{11}$ \\
\hline 1-methyl-2- $n$-propyl benzene & $2.2( \pm 0.9) \times 10^{-4}$ & $1.8( \pm 0.4) \times 10^{-4}$ & $1.5( \pm 0.4) \times 10^{-4}$ & $1.0 \times 10^{-11}$ & $(* *)^{11}$ \\
\hline 1,2-dimethyl-3-ethylbenzene & $2.6( \pm 0.9) \times 10^{-4}$ & $1.5( \pm 0.3) \times 10^{-4}$ & $1.4( \pm 0.3) \times 10^{-4}$ & $1.0 \times 10^{-11}$ & $(* *)^{11}$ \\
\hline 1,2,4,5-tetramethylbenzene & $1.8( \pm 0.6) \times 10^{-4}$ & $1.4( \pm 0.3) \times 10^{-4}$ & $1.4( \pm 0.2) \times 10^{-4}$ & $1.0 \times 10^{-11}$ & $(* *)^{11}$ \\
\hline 1,2,3,4-tetramethylbenzene & $1.5( \pm 0.2) \times 10^{-4}$ & $1.3( \pm 0.3) \times 10^{-4}$ & $1.4( \pm 0.3) \times 10^{-4}$ & $1.0 \times 10^{-11}$ & $(* *)^{11}$ \\
\hline \multicolumn{6}{|l|}{ Aldehydes and ketones } \\
\hline nonanal & $2.6( \pm 1.5) \times 10^{-1}$ & $1.7( \pm 1.2) \times 10^{-1}$ & $1.5( \pm 0.4) \times 10^{-1}$ & $3.0 \times 10^{-11}$ & $(* *)^{12}$ \\
\hline heptanal & $1.7( \pm 0.6) \times 10^{-1}$ & $1.1( \pm 0.5) \times 10^{-1}$ & $7.9( \pm 3.0) \times 10^{-2}$ & $3.0 \times 10^{-11}$ & (a) \\
\hline hexanal & $1.1( \pm 3.3) \times 10^{-1}$ & $7.2( \pm 2.6) \times 10^{-2}$ & $6.6( \pm 1.5) \times 10^{-2}$ & $3.0 \times 10^{-11}$ & (a) \\
\hline pentanal & $4.3( \pm 1.6) \times 10^{-2}$ & $3.9( \pm 1.7) \times 10^{-2}$ & $3.7( \pm 1.0) \times 10^{-2}$ & $9.9 \times 10^{-11} \exp (310 / \mathrm{T})$ & (a) \\
\hline butanal & $2.6( \pm 1.2) \times 10^{-2}$ & $2.7( \pm 0.6) \times 10^{-2}$ & $3.2( \pm 0.9) \times 10^{-2}$ & $6.0 \times 10^{-12} \exp (410 / \mathrm{T})$ & (a) \\
\hline propanal & $2.6( \pm 1.2) \times 10^{-2}$ & $3.4( \pm 2.2) \times 10^{-2}$ & $2.3( \pm 0.9) \times 10^{-2}$ & $5.1 \times 10^{-12} \exp (405 / \mathrm{T})$ & (a) \\
\hline methyl isobutyl ketone & $2.2( \pm 0.7) \times 10^{-3}$ & $2.4( \pm 1.5) \times 10^{-3}$ & $2.5( \pm 0.7) \times 10^{-3}$ & $1.3 \times 10^{-11}$ & (a) \\
\hline acetophenone & $1.7( \pm 0.9) \times 10^{-3}$ & $1.4( \pm 0.6) \times 10^{-3}$ & $1.3( \pm 0.4) \times 10^{-3}$ & $1.0 \times 10^{-11}$ & $(* *)^{11}$ \\
\hline methyl $n$-butyl ketone & $1.1( \pm 0.5) \times 10^{-3}$ & $1.3( \pm 0.4) \times 10^{-3}$ & $1.2( \pm 0.2) \times 10^{-3}$ & $9.1 \times 10^{-12}$ & (a) \\
\hline \multicolumn{6}{|l|}{$\mathrm{CO}$} \\
\hline $\mathrm{CO}$ & $8.9( \pm 1.0) \times 10^{-1}$ & $8.9( \pm 1.2) \times 10^{-1}$ & $8.5( \pm 1.4) \times 10^{-1}$ & $2.4 \times 10^{-13}$ & (i) ${ }^{13}$ \\
\hline $\begin{array}{l}\text { a Atkinson and Arey (2003), }{ }^{\mathrm{b}} \text { Dill } \\
\mathrm{e} \text { Atkinson et al. (1992), }{ }^{\mathrm{f}} \text { Atkinson } \\
1 \text { Rate expression is for 2-methylpe } \\
2 \text { Rate expression is for 2,4-dimethy } \\
3 \text { Value is generic for } \sim \mathrm{C}_{7}+\mathrm{OH} \text { at } \\
4 \text { Rate constant is for ethylcyclopen } \\
5 \text { Value is generic for } \sim \mathrm{C}_{8}+\mathrm{OH} \text { a } \\
6 \text { Value is generic for branched } \sim \mathrm{C} \\
7 \text { Rate expression is for } 1 \text {-butene }+ \\
8 \text { Rate constant is for cyclohexene } \\
9 \text { Rate constant is an average of } m- \\
10 \text { Rate constant is an average of } m \\
11 \text { Value is generic for an aromatic } \\
12 \text { Rate constant is for heptanal }+\mathrm{C} \\
13 \text { Listed value is at } 298 \mathrm{~K} \text {. In our a }\end{array}$ & $\begin{array}{l}\text { et al. }(2005),{ }^{c} \text { Yamada et al. }( \\
t \text { al. }(2001),{ }^{g} \text { Calvert et al. }(20 \\
\text { tane }+\mathrm{OH} \text {. } \\
\text { pentane }+\mathrm{OH} \text {. } \\
98 \mathrm{~K} \text {. } \\
\text { ane }+\mathrm{OH} \text { at } 298 . \\
298 \mathrm{~K} \text {. } \\
\text { cycloalkane }+\mathrm{OH} \text { at } 298 \mathrm{~K} \text {. } \\
\mathrm{H} \text {. } \\
\mathrm{OH} \text { at } 298 \mathrm{~K} \text {. } \\
\text { nd } p \text {-xylene }+\mathrm{OH} \text { at } 298 \mathrm{~K} \text {. } \\
\text { and } p \text {-ethyltoluene }+\mathrm{OH} \text { at } 298 \\
\mathrm{OH} \text { at } 298 \mathrm{~K} \text {. } \\
\mathrm{H} \text { at } 298 \mathrm{~K} \text {. }\end{array}$ & $\begin{array}{l}\text { 003), }{ }^{\mathrm{d}} \text { Sprengnether et al. (20 } \\
\text { 2), }{ }^{\mathrm{h}} \text { Atkinson et al. (1994), }{ }^{\mathrm{i}} \mathrm{S}\end{array}$ & nder et al. (2003). & & \\
\hline
\end{tabular}




\section{Appendix C}

\section{EPA PAMS data set}

The US Environmental Protection Agency (EPA) Photochemical Assessment Monitoring Stations (PAMS) network (http://www.epa.gov/ttnamti1/pamsmain.html) monitors a variety of organic molecules heavily weighted toward anthropogenic, unfunctionalized hydrocarbons emitted from light-duty vehicles. VOC samples are collected $\sim 4$ times per day during the summer at three stations in the southern SJV: Shafter $\left(35.504^{\circ} \mathrm{N}, 119.272^{\circ} \mathrm{W}\right)$, Golden Street Avenue $\left(35.386^{\circ} \mathrm{N}, 119.015^{\circ} \mathrm{W}\right)$, and Arvin Bear Mountain Boulevard $\left(35.208^{\circ} \mathrm{N}, 118.784^{\circ} \mathrm{W}\right)$. We use the median of all data in a given year collected within the time interval of 10:00-17:00 LT, as a result we may include 0,1 , or 2 data points from 1,2, or 3 sites per day. We chose toluene to represent the trend in the temperature-independent $\Sigma_{i} \mathrm{VOCR}_{i}$, as (a) its daily average reactivity during CalNex-SJV was temperature-independent and (b) it was well sampled by the PAMS network 2001-2009. We compute the rate of decrease of VOCR toluene to be $\sim 6 \% \mathrm{yr}^{-1}$ over this time period.

We use the PAMS 2010 benzene/toluene and ethane/propane ratios $(10: 00-17: 00 \mathrm{LT})$ to scale the CalNex-SJV observations of toluene and propane for $\mathrm{VOCR}_{\text {benzene }}$ and $\mathrm{VOCR}_{\text {ethane }}$.
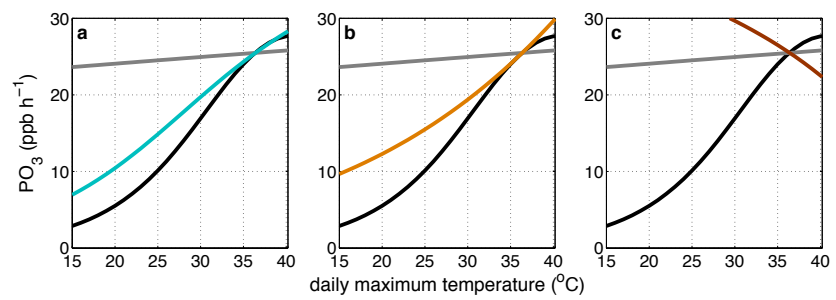

Fig. D1. $\mathrm{PO}_{3}\left(\mathrm{ppbh}^{-1}\right)$ at weekday $\mathrm{NO}_{\mathrm{x}}$ versus daily maximum temperature $\left({ }^{\circ} \mathrm{C}\right)$. The solid black curves are the same as in Fig. 7a-c. The gray curves are $P_{3}$ at the high temperature average $\left(36.4{ }^{\circ} \mathrm{C}\right) \mathrm{VOCR}, P \mathrm{HO}_{\mathrm{x}}$, and $\mathrm{NO} / \mathrm{NO}_{\mathrm{x}}$ values with rate constants that are allowed to be temperature dependent. (a) $\mathrm{PO}_{3}$ with temperature-dependent VOCR $\left(\mathrm{NO} / \mathrm{NO}_{\mathrm{x}}\right.$ and $P \mathrm{HO}_{\mathrm{x}}$ are constant). (b) $\mathrm{PO}_{3}$ with temperature-dependent $P \mathrm{HO}_{\mathrm{x}}$ (VOCR and $\mathrm{NO} / \mathrm{NO}_{\mathrm{x}}$ are constant). (c) $\mathrm{PO}_{3}$ with temperature-dependent $\mathrm{NO} / \mathrm{NO}_{\mathrm{x}}\left(\mathrm{VOCR}\right.$ and $P \mathrm{HO}_{\mathrm{x}}$ are constant).

\section{Appendix D}

\section{Impacts on $\mathrm{PO}_{3}$ from future changes in $\mathrm{PHO}_{x}$ and $\mathrm{NO} / \mathrm{NO}_{\mathrm{x}}$}

In Fig. 7 we tested three primary (direct) emissions control scenarios. Future changes in $P \mathrm{HO}_{\mathrm{x}}$ and $\mathrm{NO} / \mathrm{NO}_{\mathrm{x}}$ will also impact $P_{3}$, which we did not include in our three scenarios. Feedback effects result in changes to these parameters but have little effect on our conclusions. In Fig. D1, $\mathrm{PO}_{3}$ is computed both with all parameters varying with temperature (at weekday $\mathrm{NO}_{\mathrm{x}}$ ) (black) and with constant high-temperature $\left(36.4^{\circ} \mathrm{C}\right.$ ) average values (the rate coefficients do vary with temperature) (gray). We test the temperature-dependent variables separately: VOCR (panel a), $P \mathrm{HO}_{\mathrm{x}}$ (panel b), and $\mathrm{NO} / \mathrm{NO}_{\mathrm{x}}$ (panel c). First, decreases in $\mathrm{O}_{3}$ decrease $P \mathrm{HO}_{\mathrm{x}}$ and increase $\mathrm{NO} / \mathrm{NO}_{\mathrm{x}}$. For example, allowing $\mathrm{O}_{3}$ to be $50 \%$ the $\mathrm{HO}_{\mathrm{x}}$ source, a $20 \%$ reduction in $\mathrm{O}_{3}$ effects an approximately $10 \%$ decrease in $\mathrm{PHO}_{\mathrm{x}}$. This same decrease in $\mathrm{O}_{3}$ increases $\mathrm{NO} / \mathrm{NO}_{\mathrm{x}}$ by $25 \%$ (at $80 \mathrm{ppb} \mathrm{O}_{3}, 5 \mathrm{ppb} \mathrm{NO}, 300 \mathrm{~K}$, and $j_{\mathrm{NO}_{2}}=0.009 \mathrm{~s}^{-1}$ ). The two effects are near equal in magnitude and opposite in sign. Second, VOC emissions reductions work to decrease $P \mathrm{HO}_{\mathrm{x}}$, as $\mathrm{H}_{2} \mathrm{CO}$ is, at some point, an oxidation product of nearly every organic molecule. $\mathrm{H}_{2} \mathrm{CO}$ is $\sim 25 \%$ of $P \mathrm{HO}_{\mathrm{x}}$ during CalNex-SJV. If $\mathrm{H}_{2} \mathrm{CO}$ decreases over the next decade according to Fig. 3 , then a $15 \%$ decrease (the upper bound) in $\mathrm{H}_{2} \mathrm{CO}$ at high temperatures decreases $P \mathrm{HO}_{\mathrm{x}}$ by less than $5 \%$, also at high temperatures, an effect too small to alter our conclusions. 